7

\title{
Functional basis for calmodulation of the TRPV5 calcium channel
}

$$
\begin{gathered}
\text { Sara R Roig }{ }^{1,2} \text {, Niky Thijssen }{ }^{1} \text {, Merijn van Erp }{ }^{3} \text {, } \\
\text { Jack Fransen }{ }^{3} \text {, Joost G Hoenderop }{ }^{1} \text {, Jenny van der Wijst }{ }^{1}
\end{gathered}
$$

${ }^{1}$ Department of Physiology, Radboud Institute for Molecular Life Sciences, Radboud university medical center, Nijmegen, the Netherlands ${ }^{2}$ Imaging Core Facility, Biozentrum, University of Basel, Basel, Switzerland ${ }^{3}$ Radboudumc Technology Centre Microscopy, Radboud Institute for Molecular Life Sciences, Radboud university medical center, Nijmegen, the Netherlands

Correspondence to: Jenny van der Wijst, PhD

Department of Physiology

Radboud Institute for Molecular Life Sciences

Radboud university medical center

P.O. Box 9101, $6500 \mathrm{HB}$, Nijmegen, the Netherlands

Email: jenny.vanderwijst@radboudumc.nl

Phone: +31-24-3617347 


\section{Abstract}

35 Within the transient receptor potential (TRP) superfamily of ion channels, TRPV5 is a highly

$36 \mathrm{Ca}^{2+}$-selective channel important for active reabsorption of $\mathrm{Ca}^{2+}$ in the kidney. Its channel

37 activity is controlled by a negative feedback mechanism involving calmodulin (CaM) binding.

38 Combining advanced microscopy techniques and biochemical assays, this study

39 characterized the dynamic bilobal CaM regulation and binding stoichiometry. We

40 demonstrate for the first time that functional (full-length) TRPV5 interacts with CaM in the

41 absence of $\mathrm{Ca}^{2+}$, and this interaction is intensified at increasing $\mathrm{Ca}^{2+}$ concentrations sensed

42 by the CaM C-lobe that achieves channel pore blocking. Channel inactivation occurs without

43 CaM N-lobe calcification. Moreover, we reveal a 1:2 stoichiometry of TRPV5:CaM binding by

44 implementing single molecule photobleaching counting, a technique with great potential for

45 studying TRP channel regulation. In conclusion, our study proposes a new model for CaM-

46 dependent regulation - calmodulation - of the $\mathrm{Ca}^{2+}$-selective TRPV5 that involves apoCaM

47 interaction and lobe-specific actions. 


\section{Introduction}

Transient receptor potential (TRP) channels are one of the largest classes of ion channels and are widely expressed throughout the animal kingdom (1). Since their discovery, they have emerged as key players in human physiology and were found to be associated with various diseases, such as cancer, skeletal abnormalities, skin disorders, and chronic pain (2,

3). The mammalian TRP family consists of six subfamilies; canonical (TRPC), melastatin (TRPM), vanilloid (TRPV), polycystin (TRPP), ankyrin (TRPA) and mucolipin (TRPML), categorized based on sequence homology (4).

Yet, there is a striking variability in their channel properties in contrast to other families of ion channels. While most TRP channels are rather non-selective for ion permeation, TRPV5 and its close homologue TRPV6 exhibit a highly selective calcium $\left(\mathrm{Ca}^{2+}\right)$ permeability $(5,6)$. This concurs with their transport function in $\mathrm{Ca}^{2+}$ (re)absorbing epithelia of the kidney and intestine. Functionally, the channels utilize a $\mathrm{Ca}^{2+}$-dependent feedback mechanism to achieve a fast channel inactivation and slow current decay $(7,8)$. Over the years, it has been established that (part of) this regulation occurs via interaction with the $\mathrm{Ca}^{2+}$-binding protein calmodulin (CaM) (9-14).

67 CaM regulation is well studied across voltage-gated $\mathrm{Ca}^{2+}$ channels $\left(\mathrm{Ca}_{\mathrm{v}}\right)$, where it is also referred to as 'calmodulation' (15). CaM consists of amino (N)-terminal and carboxy (C)terminal lobes, each containing two EF hand pairs capable of binding $\mathrm{Ca}^{2+}$, that are joined by a flexible central linker. CaM can customize channel regulation by binding $\mathrm{Ca}^{2+}$ to either its $\mathrm{N}$ - or C-lobe and evoke lobe-specific channel modulation. Moreover, it is known to bind $\mathrm{Ca}_{\mathrm{v}}$ channels in its $\mathrm{Ca}^{2+}$-free state (apoCaM), and can consequently transduce relevant signals upon $\mathrm{Ca}^{2+}$ binding (15). Hence, a prominent feedback mechanism can tune channel gating, and thus regulate $\mathrm{Ca}^{2+}$ influx in accordance with cytosolic $\mathrm{Ca}^{2+}$ signals. While $\mathrm{CaM}$ is known 
bioRxiv preprint doi: https://doi.org/10.1101/2021.02 16.431366 this version posted February 16, 2021. The copyright holder for this preprint (which was not certified by peer review) is the author/funder, who has granted bioRxiv a license to display the preprint in perpetuity. It is made available under aCC-BY 4.0 International license.

to bind various TRP channels, including TRPV5/6, surprisingly little is known about such 'TRP calmodulation' regarding the dynamics of the process and stoichiometry of binding.

Importantly, technological advances in single particle cryo-electron microscopy (cryo-EM) have demonstrated the transformative power for generating high resolution structures of TRP channels. Three independent groups, including ours, have provided detailed structural insight into TRPV5 and TRPV6 in complex with CaM (16-18). All structures were resolved upon purifying the complex in buffers containing a high $\mathrm{Ca}^{2+}$ concentration $\left(\left[\mathrm{Ca}^{2+}\right] ; 5 \mathrm{mM}\right)$. This universally demonstrated binding of the CaM N-and C-lobes to respectively proximal and distal C-terminal regions of the channel (16-18). Moreover, a general blockade mechanism was shown by the side chain of K115 of the CaM C-lobe that protrudes into the channel pore. However, one of the important differences is the complex stoichiometry. Singh et al. and Hughes et al. showed that both the TRPV6-CaM and TRPV5-CaM, respectively, exhibit 1:1 stoichiometry (18), while a flexible 1:2 stoichiometry of 1 tetrameric channel binding to 2 CaM molecules was postulated based on our TRPV5-CaM complex structure (16). In order to fully understand channel regulation, it is highly significant to unravel the dynamic interaction of CaM with TRPV5, including apoCaM binding, lobespecific effects and binding stoichiometry.

Using a combination of Förster Resonance Energy Transfer (FRET)-based Fluorescence Lifetime Imaging Microscopy (FLIM; FLIM-FRET) and Fura-2 $\mathrm{Ca}^{2+}$ imaging, we revealed that apoCaM is pre-associated with TRPV5. The $\mathrm{Ca}^{2+}$-insensitive CaM mutants, where either two EF hands (CaM12 or CaM34) or all four EF hands (CaM1234) were mutated, showed that calcification of the CaM C-lobe is essential for channel inactivation, while a calcified N-lobe appears not critical for TRPV5 inhibition. In contrast to previously proposed concepts $(9,10)$, this suggests that the $\mathrm{CaM} \mathrm{N}$-lobe does not function as a $\mathrm{Ca}^{2+}$ sensor towards rearranging 
bioRxiv preprint doi: https://doi org/10.1101/2021.02 16.431366; this version posted February 16, 2021. The copyright holder for this preprint (which was not certified by peer review) is the author/funder, who has granted bioRxiv a license to display the preprint in perpetuity. It is made available under aCC-BY 4.0 International license. Fluorescence Lifetime Imaging Microscopy (FLIM) to unravel the $\mathrm{Ca}^{2+}$-dependency of

$117 \mathrm{Ca}^{2+}$-insensitive mutants of CaM (CaM, CaM12, CaM34, CaM1234) were fused to eGFP, and

118 co-expressed with mCherry or mCherry-tagged TRPV5 in HEK293 cells (Figure 1A-B). These

119 CaM mutants are deficient in binding $\mathrm{Ca}^{2+}$ due to point mutations in the N-lobe EF hands 120 (CaM12), C-lobe EF hands (CaM34) or all four EF hands (CaM1234). Expression and 121 distribution of all CaM mutants resembles CaM wildtype (Figure 1A). Co-expression with 122 TRPV5 shifted the distribution of CaM and CaM12 from a whole-cell staining to an 
bioRxiv preprint doi: https://doi.org/10.1101/2021.02 16.431366; this version posted February 16, 2021. The copyright holder for this preprint (which was not certified by peer review) is the author/funder, who has granted bioRxiv a license to display the preprint in perpetuity. It is made available under aCC-BY 4.0 International license.

extranuclear distribution (Figure 1A). Lifetime decay $(\tau)$ measurements performed in areas of co-localization showed a significantly decreased $\tau$ of eGFP in cells co-expressing TRPV5 with CaM or CaM12 (Figure 1B). CaM34 and CaM1234 distributed mainly in the nuclei showing high values of decay due to its concentration. Importantly, only extranuclear ROls were analysed, to compare between mock and TRPV5 conditions as TRPV5 is not localized in the nuclei. CaM1234 depicted a modest but significant decrease of lifetime decay, once coexpressed with TRPV5. Interestingly, CaM34 does not show any changes in $\tau$ (Figure 1B). Thereby, CaM, CaM12 and CaM1234 have the potential to interact with TRPV5, indicating that the CaM N-lobe does not need to calcified in order to bind TRPV5.

We confirmed these results by co-immunoprecipitation of GFP-TRPV5 with GST-tagged CaM wildtype and mutants (Figure 1C). All CaM proteins demonstrated similar expression by equal pull-down with GST-sepharose resin (Figure 1C, pulldown GST). TRPV5 shows a clear interaction with CaM and CaM12. In line with the FLIM-FRET results, CaM1234 maintains the capability of interacting with TRPV5, albeit to lesser extent compared to CaM WT or CaM12, while CaM34 shows little-to-no interaction with TRPV5 (Figure 1C, pulldown GST). Of note, total lysate shows equal expression of all proteins (Figure $1 \mathbf{C}$, total lysate).

CaM consists an N-lobe and C-lobe that each bind $\mathrm{Ca}^{2+}$ at different affinity (20). While the Clobe presents a 10 -fold higher affinity than the N-lobe, the kinetics is much slower (20). To understand the magnitude of $\mathrm{Ca}^{2+}$-dependency of CaM interaction with TRPV5, and the contribution of each lobe, a CaM agarose pull-down of TRPV5-expressing HEK293 cells was performed under different $\mathrm{Ca}^{2+}$ concentrations mimicking intracellular $\mathrm{Ca}^{2+}$ levels $(0-10 \mu \mathrm{M})$ (Figure 1D). These were calculated as described in the Methods. Interestingly, we observed a weak interaction with TRPV5 in the absence of $\mathrm{Ca}^{2+}$, that was intensified upon increasing 
$147 \mathrm{Ca}^{2+}$ concentrations (Figure 1D-E). Most notably, significant interaction was already

148 detectable at $10 \mathrm{nM} \mathrm{Ca}^{2+}$. Based on literature (20), only the C-lobe is loaded with $\mathrm{Ca}^{2+}$ at this

149 specific concentration, responsible for the $\mathrm{Ca}^{2+}$-dependent interaction. These results point

150 towards a pre-existing TRPV5-CaM interaction at $\mathrm{Ca}^{2+}$ basal concentrations.

151

152 Since we also observed interaction between TRPV5 and CaM1234, we suggest that the

153 TRPV5-CaM complex remains even if $\mathrm{Ca}^{2+}$ decreases in specific subcellular areas. Yet, it

154 might be argued that CaM1234 is structurally different to apoCaM and does not represent a

155 physiological setting. To understand the apoCaM interaction, we performed by FLIM-FRET

156 on PMLs. Importantly, these PMLs were prepared by unroofing the cells (Figure 1 - figure

157 supplement $\mathbf{1 A}$ ) and provided access to the intracellular compartment. Only proteins

158 associated to the membrane remain in these preparations $(21,22)$. We first confirmed the

159 presence of TRPV5-containing membranes (Figure 1 - figure supplement 1B-C). Following,

160 we studied the presence of eGFP-CaM in PMLs treated with $\mathrm{Ca}^{2+}$-containing $(2 \mathrm{mM})$ and

$161 \mathrm{Ca}^{2+}$-free (2 mM EGTA, 2 mM EDTA) solutions. Despite that CaM is a cytosolic protein, CaM

162 and TRPV5 positively co-localized in all PML conditions (Figure 1F). FLIM-FRET

163 measurements proved that not only $\mathrm{Ca}^{2+}-\mathrm{CaM}$, but also apoCaM interacts with TRPV5,

164 although in a lesser extent (Figure 1G).

166 Interaction interface of TRPV5-CaM

167 While the recently published cryo-EM structures of the TRPV5-CaM complex revealed that

168 the CaM C-lobe is occluding the pore leading to channel inhibition $(16,17)$, no information

169 has been provided about the dynamic bilobal regulation of TRPV5. A proximal C-terminal

170 helix of TRPV5 was shown to bind the CaM N-lobe, while a distal C-terminal helix interacts 
bioRxiv preprint doi: https://doi org/10.1101/2021.02 16.431366; this version posted February 16, 2021. The copyright holder for this preprint (which was not certified by peer review) is the author/funder, who has granted bioRxiv a license to display the preprint in perpetuity. It is made available under aCC-BY 4.0 International license.

171 with the CaM C-lobe $(16,17)$. To investigate the importance of the independent CaM lobes

172 in binding TRPV5, we synthesized peptides of the corresponding TRPV5 helices - proximal

173 peptide and distal peptide (Figure 2A). Binding of these peptides to CaM was assessed by a

174 peptide pull-down on wildtype CaM-expressing HEK293 cells (Figure 2B). This demonstrated

175 that CaM interacts with both TRPV5 peptides (Figure 2B). Furthermore, the peptides were

176 used in a peptide competition assay to analyse differences in binding affinity to CaM.

177 Addition of increasing amounts of peptide $(0-100 \mu \mathrm{M})$ to a CaM agarose pull-down of

178 TRPV5-expressing HEK293 cell lysates revealed decreased binding of TRPV5 to CaM-agarose

179 by the distal peptide (Figure $\mathbf{2 C}$ ). Addition of the proximal peptide resulted in significant less

180 changes, suggesting a specific competition of the distal peptide (Figure 2C). Non-linear

181 fitting of the curves to the log concentration revealed a sigmoidal correlation $\left(R^{2}=0.942\right)$ for

182 the distal peptide (Figure 2E), while no correlation was observed $\left(R^{2}=0.188\right.$ ) for the

183 proximal peptide (Figure 2D). Based on the fitted formula describing the graph, we

184 calculated an $\mathrm{IC}_{50}$ of $5.2 \mu \mathrm{M}$ of the competing distal peptide.

185

$$
y=2,19 \cdot 10^{-5}+\frac{1,011}{1+10^{(0,7192-x) *(-1,527)}}
$$

186

187 Interestingly, single alanine mutations of TRPV5 residues from either the proximal (D90A, F651A) or the distal (W702, W583A) C-terminal interaction interface did not abolish CaM binding as demonstrated by FLIM-FRET analysis (Figure 2 - figure supplement 2A/B). CaM binding of TRPV5 D90A and TRPV5 W702A was slightly less compared to TRPV5 wildtype

191 (Figure 2 - figure supplement 2B). Given the interaction between CaM1234 and TRPV5

192 (Figure 1B), we explored the potential involvement of these residues in the interaction and 
bioRxiv preprint doi: https://doi.org/10.1101/2021.02.16.431366; this version posted February 16, 2021. The copyright holder for this preprint (which was not certified by peer review) is the author/funder, who has granted bioRxiv a license to display the preprint in perpetuity. It is made available under aCC-BY 4.0 International license.

193 found that CaM1234 exhibited the same ability for interacting to all TRPV5 mutants (Figure

$194 \quad 2$ - figure supplement 2 C).

195

Lobe-dependent interaction in relation to TRPV5 function

197 To corroborate our interaction studies and evaluate the bilobal role of CaM on TRPV5

198 activity, we performed Fura-2 $\mathrm{Ca}^{2+}$ imaging of HEK293 cells expressing TRPV5 with

199 endogenous CaM, or overexpression with wildtype or mutant CaMs (Figure 3A). The TRPV5-

200 expressing cells showed a peak response with plateau after addition of $\mathrm{Ca}^{2+}$, which was

201 significantly reduced upon co-expression with wildtype CaM (Figure 3A/B). Interestingly, co-

202

expression with CaM12 also resulted in a reduction, suggesting an impaired but remaining

ability to inhibit TRPV5. Contrarily, co-expression with CaM1234 or CaM34 yielded an

increased $\mathrm{Ca}^{2+}$ peak response compared to endogenous CaM (Figure 3A/B). This implies

that CaM1234 or CaM34 can interfere with endogenous CaM binding via a competitive

interaction to TRPV5. As has been suggested by others, it thereby has counteracting effect

207

on endogenous CaM-dependent inhibition (23). This data indicates that the CaM C-lobe $\mathrm{Ca}^{2+}$

208 sensitivity is crucial for TRPV5 inactivation, while the $\mathrm{N}$-lobe does not need to be calcified

209 and may have a support role.

210 It led us to generate single $\mathrm{N}$ - and C-lobes to evaluate whether the lobes can act

211 independently on TRPV5. Following similar steps as abovementioned, we first addressed the

212 interaction capability of both lobes. Either $\mathrm{N}$ - or C-lobe of CaM could effectively interact

213 with TRPV5, as shown by the reduction on lifetime decay (Figure 3C, Figure $\mathbf{3}$ - figure

214 supplement 3). The specific interaction of the independent lobes with the TRPV5 helices

215 was studied in a peptide pull-down of HEK293 cells expressing CaM N- or C-lobe (Figure 3D).

216 In line with the structural findings of $\operatorname{TRPV} 5-\operatorname{CaM}(16,17)$, most significant binding was 
bioRxiv preprint doi: https://doi.org/10.1101/2021.02 16.431366 this version posted February 16, 2021. The copyright holder for this preprint (which was not certified by peer review) is the author/funder, who has granted bioRxiv a license to display the preprint in perpetuity. It is made available under aCC-BY 4.0 International license.

observed between the CaM C-lobe and the distal TRPV5 peptide. Notably, there was also weak but consistent interaction of the N-lobe with both peptides (Figure 3D). Next, we

219 addressed the potential independent effect on TRPV5 function. Fura-2 $\mathrm{Ca}^{2+}$ imaging demonstrated that co-expression of TRPV5 with either CaM N- or C-lobe increases the intracellular $\mathrm{Ca}^{2+}$ peak compared to TRPV5 with endogenous or overexpressed wildtype TRPV5, full length CaM is needed for TRPV5 inhibition.

We further explored the interaction of each $\mathrm{CaM}$ lobe in $\mathrm{Ca}^{2+}$-free conditions using FLIMFRET analysis of PMLs from cells co-expressing TRPV5 and CaM N- or C-lobe. While CaM and apoCaM interact with TRPV5, the $\mathrm{N}$ - and $\mathrm{C}$ - lobe interact in $\mathrm{Ca}^{2+}$-containing ( $\left.2 \mathrm{mM}\right)$, but not in $\mathrm{Ca}^{2+}$-free (2 mM EGTA, 2 mM EDTA) conditions (Figure 3G-J). Summing up, the C-lobe is the major entity for sensing $\mathrm{Ca}^{2+}$ changes and closing TRPV5. The N-lobe (and the linker) act as a support to the structural rearrangement required for the C-lobe to execute its function.

In addition to the dynamics of TRPV5-CaM binding, the stoichiometry of the TRPV5-CaM complex is still under debate. Recent structural work by our group provided evidence for binding of either 1 or 2 CaM molecules (16) to the tetrameric channel, while other groups have described a 1:1 stoichiometry for $\operatorname{TRPV5:CaM}$ as well as for $\operatorname{TRPV6} 6 \mathrm{CaM}(9,10,17,18)$. To this end, we implemented a method to reveal the in vivo stoichiometry of TRPV5-CaM, which is single molecule photobleaching counting (smPB) (24). Following the procedure described in Methods, single molecule complexes at the cell surface were imaged using a

239 TIRF microscope for long acquisition lapses. To optimize the conditions of this technique for 240 our study, we started with HEK293 cells only expressing eGFP-TRPV5 and observed 
bioRxiv preprint doi: https://doi.org/10.1101/2021.02 16.431366 this version posted February 16, 2021. The copyright holder for this preprint (which was not certified by peer review) is the author/funder, who has granted bioRxiv a license to display the preprint in perpetuity. It is made available under aCC-BY 4.0 International license.

241 individual molecules at the TIRF plane (Figure 4A). Analysis of their traces was performed by

242 filtering them with a tailored Chung-Kennedy Filter Plugin as described previously (25).

243 Some obtained traces matched the expected number of 4 bleaching steps for a tetramer like

244 TRPV5 (Figure 4B), while there were also molecules with bleaching steps ranging from 1 to

245 3. By fitting the observed values to a binomial distribution, we could infer an eGFP folding

246 probability of 72\% (Figure 4C). Next, HEK293 cells co-expressing mCherry-TRPV5 and eGFP-

247 CaM were subjected to SmPB to analyse the stoichiometry of binding. Of note, a slightly

248 different distribution was found for mCherry-TRPV5 compared to eGFP, since the probability

249 of folding was lower ( $p=0.62$, data not shown). In order to assess stoichiometry of binding,

250 low mobile mCherry-TRPV5 spots were chosen that were also positive for eGFP (Figure 4D).

251 These were analysed in the presence and absence of extracellular $\mathrm{Ca}^{2+}$. The latter condition

252 was taken along to reduce potential changes in intracellular $\mathrm{Ca}^{2+}$ levels as a result of $\mathrm{Ca}^{2+}$

253 influx. CaM analysis revealed mainly two type of traces: one or two bleaching steps (Figure

254 4E-F). A highly reduced amount of three steps traces could be found ( $2 \%$ and $5 \%$ for

255 presence and absence of $\mathrm{Ca}^{2+}$, respectively). Fitting our results to a binomial distribution

256 with eGFP folding probability of $72 \%$ showed that the distributions fit with a preferential

257 stoichiometry of 2 CaM molecules per TRPV5 tetramer, either in the presence or absence of

258 extracellular $\mathrm{Ca}^{2+}$ (Figure 4G-H).

259

260 Discussion

261 The present study sheds new light on the dynamic interaction between TRPV5 and CaM and

262 its stoichiometry. It shows a constitutive weak interaction of TRPV5 with apoCaM, and a

263 solid interaction with $\mathrm{CaM}$ C-lobe in the presence of $10 \mathrm{nM}$ of $\mathrm{Ca}^{2+}$, mimicking basal

264 physiological conditions. Importantly, our data provided evidence that a missing CaM N-lobe 
bioRxiv preprint doi: https://doi.org/10.1101/2021.02 16.431366. this version posted February 16, 2021. The copyright holder for this preprint (which was not certified by peer review) is the author/funder, who has granted bioRxiv a license to display the preprint in perpetuity. It is made available under aCC-BY 4.0 International license.

impacts mildly on the TRPV5 inhibition, and most likely positions the CaM C-lobe. These results establish a new model of CaM-dependent inhibition of TRPV5 in which the C-lobe is responsible for both sensing $\mathrm{Ca}^{2+}$ and blocking the channel. Furthermore, we revealed a 1:2 stoichiometry of TRPV5 and CaM in native conditions.

ApoCaM was previously thought of as dormant channel accessory, minimally capable of modulating its targets, but it is now known to trigger a myriad of functionalities across various ion channel families (26). Using various approaches, we now demonstrated for the first-time an interaction between TRPV5 and apoCaM. In contrast to previous studies suggesting that the TRPV5-CaM interaction is only $\mathrm{Ca}^{2+}$-dependent $(10,11,13,27)$, our study used the full-length functional proteins in living cells. In this setting, we found that $\mathrm{Ca}^{2+}$-dependent inhibition of TRPV5 was counteracted by the presence of the $\mathrm{Ca}^{2+}$ insensitive mutant CaM1234. CaM1234 has often been used to study functional consequences of apoCaM interaction with other channels, with similar dominant-negative effects observed (28-31). It suggests that CaM1234 displaces endogenous CaM from its binding site and thereby prevents channel inhibition. In line with a previous study (32), CaM1234 did not have an effect on the close homologue TRPV6 (data not shown), suggesting that TRPV6 is only regulated by $\mathrm{Ca}^{2+} / \mathrm{CaM}$. One might speculate that this partly underlies the difference in kinetics of channel inactivation, but further studies need to be conducted to structurally understand this distinction between TRPV5 and TRPV6.

Other examples of pre-association of apoCaM include $\mathrm{Ca}_{v} 1.2$ and $\mathrm{Ca}_{v} 2.1$, where it is shown to act as a vigilant sensor regulating channel opening (15). Such regulation is also widely studied in voltage-gated potassium $\left(\mathrm{K}_{\mathrm{v}}\right)$ and sodium channels $\left(\mathrm{Na}_{\mathrm{v}}\right)$ (33-35). Recent X-Ray crystallography experiments showed the dynamic rearrangement in the Kv7.1, Kv7.4 and 
bioRxiv preprint doi: https://doi.org/10.1101/2021.02 16.431366 this version posted February 16, 2021. The copyright holder for this preprint (which was not certified by peer review) is the author/funder, who has granted bioRxiv a license to display the preprint in perpetuity. It is made available under aCC-BY 4.0 International license.

289 Kv7.5 structure of apoCaM and $\mathrm{Ca}^{2+} / \mathrm{CaM}(36)$. Interestingly, TRPV5 is not known to exhibit

290 an IQ calmodulin-binding motif, a feature of many $\mathrm{Ca}_{\mathrm{v}}$ and $\mathrm{Na}_{\mathrm{v}}$ channels. Future studies

291 should delineate the exact interaction domain of apoCaM.

292

293 An important feature of channel regulation by CaM is the fact that the $\mathrm{N}$ - and C-lobes can

294 independently affect channel properties. This is likely due to vastly different affinities (and

295 dissociation kinetics) for $\mathrm{Ca}^{2+}$, which in turn can be altered through binding to their targets

296 (26). Once calcified, CaM undergoes a conformational change that likely induces a structural

297 rearrangement within the target proteins to produce a response (26). Generally, the C-lobe

298 presents a higher affinity for $\mathrm{Ca}^{2+}$, with the $\mathrm{N}$-lobe requiring higher intracellular $\mathrm{Ca}^{2+}$

299 concentrations to be calcified (37). Free intracellular $\mathrm{Ca}^{2+}$ can be variable depending on

300 cellular cell cycle, external insults, amongst other factors. Commonly, mammalian cells are

301 endowed with an average of $100 \mathrm{nM}$ free intracellular $\mathrm{Ca}^{2+}(38)$. At this $\mathrm{Ca}^{2+}$ concentration,

302 we observed a significant TRPV5-CaM interaction that is likely engaged by a calcified C-lobe,

303 while the N-lobe will remains empty (20). Concomitant with our results, Bokhovchuk and

304 colleagues also described a tight interaction between the CaM C-lobe and the TRPV5 C-

305 terminus at basal $\mathrm{Ca}^{2+}$ concentrations (10-100nM) (10). Specifically, we demonstrated that

306 the full-length CaM interaction mainly relies on C-lobe binding to the distal TRPV5 C-

307 terminal helix, as no competition on TRPV5-CaM interaction was observed by the proximal

308 TRPV5 C-terminus peptide. Of note, these distal and proximal peptides are based on helices

309 defined in the cryo-EM TRPV5-CaM structures that were shown to interact with C-lobe and

$310 \mathrm{~N}$-lobe, respectively $(16,17)$. Together, this would be in line with the previously proposed

311 model of CaM-dependent inhibition of TRPV5 (and TRPV6) involving the N-lobe as $\mathrm{Ca}^{2+}$

312 sensor that merely triggers channel closure upon increasing $\mathrm{Ca}^{2+}$ concentrations $(9,10,16$, 
bioRxiv preprint doi: https://doi.org/10.1101/2021.02 16.431366. this version posted February 16, 2021. The copyright holder for this preprint (which was not certified by peer review) is the author/funder, who has granted bioRxiv a license to display the preprint in perpetuity. It is made available under aCC-BY 4.0 International license.

313 18, 39). However, our findings suggest that the C-lobe acts as both the sensing and

314 executing unit of CaM. Mutation on the $\mathrm{N}$-lobe (CaM12) did result in CaM-dependent

315 channel inactivation, while an opposite effect was seen for the CaM34 and CaM1234

316 mutants. The relevance of the C-lobe modulating ion channel activity has been described for

317 other channels, such as of the Kv7 family (Kv7.1, Kv7.4 and Kv7.5) (36).

319 In addition to these CaM lobe-specific effects, it has been also described for several ion channel families that interaction with both lobes is required to trigger complete $\mathrm{Ca}^{2+}$ dependent inhibition $(15,40)$. This is likely due to a structural rearrangement of the full complex. Indeed, our experiments with single CaM lobes revealed that, while the calcified Clobe can interact with the channel, it requires an additional part of the CaM structure to fully trigger full $\mathrm{Ca}^{2+}$-dependent inactivation of TRPV5. Therefore, we propose a calmodulation model in which TRPV5 and apoCaM are pre-associated (Figure 5, left panel) to induce fast, yet non-persistent, closure of the lower channel gate upon calcification of the C-lobe of CaM at locally increased intracellular $\mathrm{Ca}^{2+}$ concentrations (Figure 5, central panel).

328 Upon a further raise in the intracellular $\mathrm{Ca}^{2+}$ concentration, the $\mathrm{N}$-lobe will become calcified and acts as stabiliser of the closed conformation (Figure 5, right panel). Upon decrease of

330 local $\mathrm{Ca}^{2+}$ (i.e. as result of $\mathrm{Ca}^{2+}$ shuttling proteins such as calbindin- $\mathrm{D}_{28 \mathrm{~K}}$ ), the complex rearranges and the CaM C-lobe will open the bottom gate.

Next to the lobe-specific effects, this study sheds new light on the stoichiometry of binding.

334 We implemented the smPB technique to decipher the amount of CaM molecules per TRPV5 tetramer (41), and identified a preferable 1:2 TRPV5-CaM composition. So far, there has 
bioRxiv preprint doi: https://doi.org/10.1101/2021.02 16.431366 this version posted February 16, 2021. The copyright holder for this preprint (which was not certified by peer review) is the author/funder, who has granted bioRxiv a license to display the preprint in perpetuity. It is made available under aCC-BY 4.0 International license.

terminus suggested a 1:2 stoichiometry for CaM:TRPV5 ${ }^{696-729}(12)$. Later studies of the same group, using longer TRPV5 C-terminus peptides, confirmed these results (10). Yet, recent cryo-EM complex structures of TRPV5 with CaM suggest on one hand a 1:1 stoichiometry of 1 tetrameric TRPV5 channel binding to 1 CaM molecule (17), and on the other hand provide evidence for a variable stoichiometry of either 1:1 or 1:2 (2 CaM molecules per TRPV5 tetramer) (16). Through the smPB method, we were the first to reveal in intact cells that TRPV5 preferably binds 2 CaM molecules.

344 Since some ion channels undergo changes in stoichiometry depending on the $\mathrm{Ca}^{2+}$ 345 concentration, experiments were performed in the presence and absence of $\mathrm{Ca}^{2+}(42)$. For example, the stoichiometry of L-type voltage-gated $\mathrm{Ca}^{2+}$ channels was found to be $1: 1$ in the absence of intracellular $\mathrm{Ca}^{2+}$, but increased to two $\mathrm{CaM}$ peptides at higher $\mathrm{Ca}^{2+}$ concentrations (43). We observed the same stoichiometry in the presence and absence of extracellular $\mathrm{Ca}^{2+}$, suggesting that basal interaction with $\mathrm{CaM}$ is not dependent on $\mathrm{Ca}^{2+}$ 350 influx. Analyzing our cryo-EM TRPV5-CaM complex structure (16), it is clear that only 1 CaM molecule can occupy the lower cavity of the tetrameric channel pore. Therefore, we would speculate that the CaM-mediated TRPV5 inactivation mimics the ball-and-chain mechanism observed between Kv channels and $K v \beta$ subunits (44). a dynamic process involving $2 \mathrm{CaM}$ molecules in close proximity to the channel pore that exhibit lobe-specific regulation. The results established a weak, but persistent, interaction between TRPV5 and apoCaM that may assist fast channel inhibition through calcification of the CaM C-lobe in close vicinity of the channel. Hereby, the $\mathrm{N}$-lobe serves primarily as 360 stabiliser of the inactivated TRPV5-CaM complex. 
Materials and Methods

363

364

Molecular cloning

365 Restriction enzyme digestions, DNA ligations and other recombinant DNA procedures were performed using standard protocols. Rabbit TRPV5 was cloned into a pcDNA5 vector containing a N-terminal GFP (green fluorescent protein) tag for biochemical assays, and a pmCherry vector containing a $\mathrm{N}$-terminal mCherry tag for microscopy experiments. Rat CaM and truncated forms of the protein, N-lobe (aa1-80) and C-lobe (aa81-149), were cloned into a peGFP vector containing a N-terminal eGFP tag for microscopy, and a pEBG vector containing a N-terminal GST tag for biochemical studies. Mutagenesis was performed to generate the indicated CaM mutants, using the QuikChange site-directed mutagenesis method (Stratagene, San Diego, USA) following manufacturer's protocol. The (partial) $\mathrm{Ca}^{2+}$ -

374 insensitive mutants CaM12, CaM34, and CaM1234 were based on mutations (D $\rightarrow A)$ in the

375 EF-hand structures of the $\mathrm{N}$ - and C-lobes, known to affect $\mathrm{Ca}^{2+}$-binding $(45,46)$. All DNA 376 constructs were verified by DNA sequencing. DNA for mammalian cell transfection was 377 amplified in E. coli TOP10f strain and plasmid preparation was done using the Macherey378 Nagel $^{\mathrm{TM}}$ Nucleobond $^{\mathrm{TM}}$ Xtra Midi kit according to manufacturers' protocol.

381 Lysis buffer: 50 mM Tris-HCl (pH 7.5), 150 mM NaCl, 2 mM EGTA, 1\% (v/v) Triton X-100, 1 $382 \mathrm{mM}$ sodium orthovanadate, $10 \mathrm{mM}$ sodium-glycerophosphate, $50 \mathrm{mM}$ sodium fluoride, 10 $383 \mathrm{mM}$ sodium pyrophosphate, $0.27 \mathrm{M}$ sucrose, and the freshly added protease inhibitors pepstatin A $(1 \mu \mathrm{g} / \mathrm{ml})$, PMSF $(1 \mathrm{mM})$, leupeptin $(5 \mu \mathrm{g} / \mathrm{ml})$, and aprotinin $(1 \mu \mathrm{g} / \mathrm{ml})$. TBS- 
Tween (TBS-T): Tris-HCL (200 mM, pH 7.5), $150 \mathrm{mM} \mathrm{NaCl}$, and 0.2\% (v/v) Tween-20. Leammli sample buffer ( $5 x)$ : 10\% (w/v) SDS, $25 \%$ (v/v) $\beta$-mercapto-ethanol, 50\% (v/v) glycerol, $0.3 \mathrm{M}$ Tris- $\mathrm{HCl}(\mathrm{pH}$ 6.8), 0.05\% (v/v) bromophenol blue. Fura-2 wash buffer: $132.0 \mathrm{mM} \mathrm{NaCl}, 4.2$ $\mathrm{mM} \mathrm{KCl}, 5.5 \mathrm{mM}$ D-glucose, $10 \mathrm{~mm}$ HEPES/Tris, pH 7.4. Fura-2 $\mathrm{Ca}^{2+}$ buffer: $132.0 \mathrm{mM} \mathrm{NaCl}$, EDTA, 5.5 mM D-glucose, 10 mm HEPES/Tris, pH 7.4. Plasma membrane lawn preparation: $70 \mathrm{mM} \mathrm{KCl}$ and $30 \mathrm{mM}$ HEPES pH 7.5, adjusted with $\mathrm{KOH}$ ( $\mathrm{KH}$ buffer).

Cell culture

HEK293 (human embryonic kidney 293) cells were grown in Dulbeccos Modified Eagles Medium (DMEM, Lonza, Basel, Switzerland) supplemented with $10 \%$ (v/v) fetal bovine serum (BioWest, Nuaillé, France), $2 \mathrm{mM}$ L-glutamine, and $10 \mu \mathrm{l} / \mathrm{ml}$ non-essential amino acids at $37^{\circ} \mathrm{C}$ in a humidity-controlled incubator with $5 \%(\mathrm{v} / \mathrm{v}) \mathrm{CO}_{2}$. For transient transfection, cells were transfected $6-8$ hours after seeding with the respective DNA construct using polyethyleneimine (PEI, Brunschwig Chemie, Basel, Switzerland) with a DNA:PEI ratio of 1:6. The cells were cultured for $16-36$ additional hours prior to the experiments.

Antibodies GFP antibody (1:5,000; G1544), GST antibody (1:5,000; G7781), and beta-actin (1:10,000; A5441) were purchased from Sigma Aldrich (Sant Luis, USA). Secondary antibodies coupled 407 to horseradish peroxidase used for immunoblotting were obtained from Sigma (A4914 Goat anti-Rabbit IgG). 


\section{Plasma membrane lawns preparation}

411 Plasma membrane lawns (PML) are cell membrane sheets obtained by unroofing cells with

412 an osmotic shock $(47,48)$. In short, HEK293 cells were seeded on $18 \mathrm{~mm}$ diameter round 413 coverslips coated with Poly-L-Lysine (PLL) and transfected with the respective plasmids. DNA 414 amounts of $650 \mathrm{ng}$ and $1350 \mathrm{ng}$ were used for transfection of donor and acceptor DNA 415 plasmids respectively. After 24 hours of transfection, cells were washed once with ice-cold 416 PBS. Membrane labelling was performed by incubating cells 10 minutes with Wheat Germ 417 Agglutinin Alexa Fluor ${ }^{\mathrm{TM}} 680$ Conjugate (WGA-AF680, Thermo Fisher Scientific, Waltham, 418 USA) diluted 1:100 in DMEM:30 mM HEPES. Next, two washes of 5 minutes with ice-cold 419 PBS were performed to remove unbound WGA-AF680. The osmotic shock was done by 420 incubating cells for 5 minutes with ice-cold KH buffer (diluted 3 times), followed by a gentle 421 wash with non-diluted $\mathrm{KH}$ buffer. In order to control the $\mathrm{Ca}^{2+}$ content, buffer modifications 422 were incorporated. In $\mathrm{Ca}^{2+}$ experimental conditions, $\mathrm{KH}$ buffer was supplemented with 2 $\mathrm{mM} \mathrm{CaCl}_{2}$, while $2 \mathrm{mM} \mathrm{EGTA}$ and $2 \mathrm{mM}$ EDTA were added for the $\mathrm{Ca}^{2+}$-free conditions. After two washes of 5 minutes with the respective ice-cold $\mathrm{KH}$ buffer, only unroofed cells remain attached. Their membranes were fixed with fresh $4 \%(\mathrm{v} / \mathrm{v})$ paraformaldehyde for 10 minutes at room temperature and mounted in Fluoromont- $\mathrm{G}^{\mathrm{TM}}$ mounting media (Thermo Fisher Scientific, Waltham, USA).

430 HEK293 cells expressing GFP-TRPV5 and GST-tagged CaM wildtype or mutants were lysed 431 (lysis buffer containing $5 \mathrm{mM} \mathrm{CaCl}_{2}$ ) 36 hours after transfection. Lysates were cleared by centrifugation at $4^{\circ} \mathrm{C}$ for 15 minutes at $16,000 \mathrm{~g}$ and protein concentration was measured by 

glutathione agarose resin (GE Healthcare, Chicago, USA) for 2 hours at $4^{\circ} \mathrm{C}$ under gentle rotation. Following three washes with lysis buffer $\left(5 \mathrm{mM} \mathrm{CaCl}_{2}\right)$, proteins were eluted in 30 $\mu \mathrm{l}$ of $2 \mathrm{X}$ Laemmli sample buffer.

437

439 The following peptides were purchased from EMC microcollections GmbH: N'-Biotin-C6hours after transfection. Lysis buffer contained $5 \mathrm{mM} \mathrm{CaCl}_{2} .1 \mathrm{mg}$ of cleared lysate was incubated with $3 \mu \mathrm{g}$ of the respective peptides for 10 minutes at $4^{\circ} \mathrm{C}$, followed by 5 minutes incubation with $20 \mu \mathrm{l}$ streptavidin agarose resin (Thermo Fisher Scientific, Waltham, USA) at $4^{\circ} \mathrm{C}$ under gentle rotation. The samples were washed three times with lysis buffer $(5 \mathrm{mM}$ $\mathrm{CaCl}_{2}$ ) and proteins were eluted in $30 \mu \mathrm{l}$ of $2 \mathrm{X}$ Laemmli sample buffer.

450 HEK293 cells expressing GFP-TRPV5 were lysed 36 hours after transfection, in buffers containing different $\mathrm{Ca}^{2+}$ concentrations as indicated. These were prepared by adding $\mathrm{CaCl}_{2}$ to the lysis buffer (containing $2 \mathrm{mM}$ EGTA) in order to obtain the indicated free $\mathrm{Ca}^{2+}$ concentrations, as calculated using MaxChelator

454 (https://somapp.ucdmc.ucdavis.edu/pharmacology/bers/maxchelator/CaEGTA-TS.htm).

Next, $1 \mathrm{mg}$ of cleared lysate was incubated with CaM agarose resin (Sigma Aldrich, San Luis, 
peptide was added during this period. The immunoprecipitates were subsequently washed

three times with lysis buffer containing the indicated $\mathrm{CaCl}_{2}$ concentration, and proteins were eluted in $30 \mu \mathrm{l}$ of $2 \mathrm{X}$ Laemmli sample buffer.

\section{Immunoblotting}

462 All samples (immunoprecipitates and total cell lysates) were subjected to $8-12 \%(w / v)$ SDS-

463 PAGE and transferred to polyvinylidene fluoride (PDVF) membranes. These membranes 464 were blocked for 30 minutes with $5 \%(\mathrm{w} / \mathrm{v})$ non-fat dry milk (NFDM; in TBS-T) and 465 immunoblotted overnight at $4^{\circ} \mathrm{C}$ using indicated primary antibodies. Next, the blots were washed with TBS-T, incubated with secondary peroxidase-labelled secondary antibodies (in $5 \%(\mathrm{w} / \mathrm{v})$ NFDM/TBS-T) for 1 hour at room temperature. Following repeated washes, protein expression was visualized with chemiluminescence SuperSignal West reagent (Thermo Fisher Scientific, Waltham, USA) using the Bio-Rad ChemiDoc XRS imaging system.

Microscopy)

473 HEK293 cells were seeded on PLL coated coverslips (18 mm diameter) and transfected with

474 indicated donor (450 ng, eGFP) and acceptor (950 ng, mCherry) plasmids, and/or 475 corresponding mock DNA for 24 hours. For PML, check Plasma membrane lawns preparation section.

477 Time-domain FLIM was performed with a 63X/1.2 numerical aperture (NA) Plan Apochromat 478 water objective lens on a Leica SP8 SMD laser scanning confocal system. Samples were 479 excited at $488 \mathrm{~nm}, 10 \%$ laser power, by a high energy pulsed IR-fiber white laser with pulses 480 of 200 ps at $80 \mathrm{MHz}$. Fluorescence photons were detected with hybrid detectors (495 nm - 
bioRxiv preprint doi: https://doi.org/10.1101/2021.02 16.431366. this version posted February 16, 2021. The copyright holder for this preprint (which was not certified by peer review) is the author/funder, who has granted bioRxiv a license to display the preprint in perpetuity. It is made available under aCC-BY 4.0 International license.

481

482

483

484

485

486

487

488

489

490

491

495

496

497

498

499

500

501

502

503

504

$545 \mathrm{~nm}$ detection range) in photon counting mode using a TCSPC approach operated by the FALCON module (Leica Microsystems, Manheim, Germany) integrated within the Leica SP8 SMD system. Cells with at least 100-1,000 photons per pixel were acquired and incorporated to the analysis. FLIM module on LASX was utilized to acquire the fluorescence decay of Regions of Interest (ROI) drawn on extranuclear donor-acceptor colocalization areas of the cell or PMLs (FALCON Leica software, Wetzlar, Germany). The $n$-Exponential Reconvolution fitting model was implemented for mono-exponential decay fitting, which also deconvoluted the instrument response function (IRF).

\section{Single Molecule Photobleaching (smPB)}

HEK293 cells were seeded on 12-well dishes and transfected with low amounts of the DNA plasmids of interest for 16 hours (100 ng TRPV5, 150 ng of CaM). Parallelly, bottom glass Willco-dishes $^{\circledR}$ (WillCo Wells B.V, Amsterdam, the Netherlands) were incubated with Concanavalin A $(2 \mathrm{mg} / \mathrm{ml})$ diluted in PBS for 30 minutes at $37^{\circ} \mathrm{C}$ and washed $\mathrm{O} / \mathrm{N}$ with PBS at the same temperate. Next, cells were resuspended with Trypsin (Lonza, Basel, Switzerland) and reseeded with fresh DMEM media (check Cell culture section) on the Willco-dishes previously prepared. Imaging was performed from 30 minutes to 5 hours post-reseeding.

Total internal reflection microscopy (TIRFM) was used for illuminating complexes located at the cell surface. To this end, we used a $150 \mathrm{X} / 1.45$ plan apochromat oil objective on an Olympus IX-71 widefield fluorescence microscope equipped with a TIRF system (Olympus, Shinjuku, Japan) and an EM-CCD camera (Hamamatsu ImagEM, Hamamatsu Photonics, Hamamatsu, Japan). eGFP and mCherry were excited with a $488 \mathrm{~nm}$ Argon laser and a 594 $\mathrm{nm}$ DPSS laser. Movies of 2,000 frames of a $54 \times 54 \mathrm{um}^{2}$ area were acquired at 30 frames per second. 
bioRxiv preprint doi: https://doi.org/10.1101/2021.02 16.431366 this version posted February 16, 2021. The copyright holder for this preprint (which was not certified by peer review) is the author/funder, who has granted bioRxiv a license to display the preprint in perpetuity. It is made available under aCC-BY 4.0 International license.

505

506

507

508

509

510

511

512

513

514

515

516

517

518

519

520

521

522

523

524

525

526

527

528

First, fluorescence from mCherry was recorded under illumination with $593 \mathrm{~nm}$ light. After most of mCherry fluorescent spots were bleached out, $593 \mathrm{~nm}$ light was switched off and subsequently $488 \mathrm{~nm}$ light turned on, and mEGFP fluorescence was recorded. Spots that stayed confined throughout the whole movie were selected for counting.

Movies were opened in Fiji (49) and confined spots were selected. To filter out the noisy traces obtained, we developed a Fiji plug-in based on the NoRSE algorithm (50), which adapted and optimised the Chung-Kennedy filter (51). Previous studies followed a similar procedure to clearly reveal the bleaching steps $(25,52,53)$. ROIs were drawn to include the confined spots no bigger than 10 pixels $^{2}$. Traces of confined spots and background areas were filtered with a sharpness factor $(p)$ of 40, a change detection range $(N)$ of 20 and 4 sample windows with sizes (M) of 4, 8, 16 and 32. Background traces were mathematically subtracted from spot traces and intensity decays were manually counted.

Intracellular $\mathrm{Ca}^{2+}$ measurements using Fura-2-AM

HEK293 cells expressing mCherry-TRPV5 and eGFP-CaM wildtype or mutants were seeded in fibronectin-coated Press-to-Seal silicone isolator wells (Molecular Probes; diameter of 2.5 $\mathrm{mm}$ ) on Superfrost Plus Microscope Slides (Thermo Fisher Scientific, Waltham, USA). After 2-4 hours, cells were loaded with $3 \mu \mathrm{M}$ Fura-2-AM and 0.01\% (v/v) Pluronic F-129 (both from Molecular Probes) in DMEM medium at $37^{\circ} \mathrm{C}$ for 20 minutes. After loading, the cells were washed twice with Fura-2 wash buffer and allowed to equilibrate for another 10 minutes in Fura-2 EDTA buffer. Next, the slide was placed on an inverted microscope (Axiovert 200M, Carl Zeiss, Jena, Germany) at 20X magnification, and intracellular $\mathrm{Ca}^{2+}$ levels were monitored after fluorescence excitation at 340 and $380 \mathrm{~nm}$ using a monochromator (Polychrome IV, TILL Photonics, Gräfelfing, Germany). Fura-2 buffer containing $\mathrm{CaCl}_{2}$ was 
bioRxiv preprint doi: https://doi.org/10.1101/2021.02 16.431366. this version posted February 16, 2021. The copyright holder for this preprint (which was not certified by peer review) is the author/funder, who has granted bioRxiv a license to display the preprint in perpetuity. It is made available under aCC-BY 4.0 International license.

added after reaching a steady basal state. Fluorescence emission light was directed by a 415DCLP dichroic mirror (Omega Optical, Inc., Brattleboro, VT) through a 510WB40 emission filter (Omega Optical Inc. Brattelboro, USA) onto a CoolSNAP HQ monochrome CCD-camera

532 (Roper Scientific, Vianen, the Netherlands). The integration time of the CCD-camera was set at 200 milliseconds with a sampling interval of 3 seconds. All hardware was controlled with wavelength, the mean fluorescence intensity was monitored in an intracellular region and, for purpose of background correction, an extracellular region of identical size, both set prior to the start of the experiment. After background correction, the fluorescence emission ratio of 340 and $380 \mathrm{~nm}$ excitation was calculated to determine changes in intracellular $\mathrm{Ca}^{2+}$ concentration. The peak response is calculated as the difference in ratio upon Fura- $2 \mathrm{Ca}^{2+}$

540 buffer addition versus basal levels in Fura-2 EDTA buffer $\left(t_{C a}-t_{E D T A}\right)$. All measurements were performed at room temperature.

544 The immunoblot data were analyzed by comparing integrated optical densities of bands

545 using Fiji (49). The semi-quantification is shown as mean \pm SEM and plotted against the log

546 free $\mathrm{Ca}^{2+}$ concentration (Figure 1E) or log peptide concentration (Figure 2). FLIM-FRET data

547 is shown as individual data points with a mean \pm SEM indicated in each graph, with $\mathrm{n}$ as the

548 number of cells. The Fura-2-AM measurements are depicted as averaged 340/380 ratio \pm

549 SEM over time, with $\mathrm{n}$ as the number of cells, and a bar graph showing the peak response

$550\left(t_{C a}-t_{E D T A}\right)$ as mean \pm SEM. For all data, $p<0.05$ was considered statistically significant using 551 a one-way ANOVA with a Dunnett's multiple comparison posthoc test. Data representation 
Inc., San Diego, USA). For the Fura-2-AM data, Graphpad was used to test for normality of

554 distribution and identify outliers. In case of non-normal distribution, a Kruskal-Wallis test

555 with Dunn's multiple comparisons test was performed.

556

\section{Acknowledgements}

We thank Mark van Goor for helpful suggestions and discussions. SRR was supported by

Alfonso Martín Escudero Grant for Postdoctoral studies abroad. This study was financially

EU Horizon 2020 Marie Skłodowska-Curie Actions (748058).

562

563 Competing interests

564 The authors declare no conflict of interest

565

\section{Author contributions}

567 SRR and JVW conceived and designed the experiments. SRR and NT performed the

568 experiments. MvE developed the Fiji Plugin for the SmPB. SRR, NT and JvW analysed the

570 supervised the work.

\section{References}

574 1. Venkatachalam K, Montell C. TRP channels. Annu Rev Biochem. 2007;76:387-417.

575 2. Nilius B. TRP channels in disease. Biochim Biophys Acta. 2007;1772(8):805-12. 
3. Wu L, Sweet TB, Clapham DE. International Union of Basic and Clinical Pharmacology. LXXVI. Current progress in the mammalian TRP ion channel family. Pharmacol Rev. 2010;62(3):381-404.

4. Clapham DE, Runnels LW, Strubing C. The TRP ion channel family. Nat Rev Neurosci. 2001;2(6):387-96

5. Nilius B, Vennekens R, Prenen J, Hoenderop JG, Bindels RJ, Droogmans G. Whole-cell and single channel monovalent cation currents through the novel rabbit epithelial $\mathrm{Ca} 2+$ channel ECaC. J Physiol. 2000;527 Pt 2:239-48.

6. Vennekens R, Hoenderop JG, Prenen J, Stuiver M, Willems PH, Droogmans G, et al. Permeation and gating properties of the novel epithelial $\mathrm{Ca}(2+)$ channel. J Biol Chem. 2000;275(6):3963-9.

7. Nilius B, Prenen J, Vennekens R, Hoenderop JG, Bindels RJ, Droogmans G. Modulation of the epithelial calcium channel, ECaC, by intracellular Ca2+. Cell Calcium. 2001;29(6):417-28.

8. Vennekens R, Droogmans G, Nilius B. Functional properties of the epithelial Ca2+ channel, ECaC. Gen Physiol Biophys. 2001;20(3):239-53.

9. Bate N, Caves RE, Skinner SP, Goult BT, Basran J, Mitcheson JS, et al. A Novel Mechanism for Calmodulin-Dependent Inactivation of Transient Receptor Potential Vanilloid 6. Biochemistry. 2018;57(18):2611-22.

10. Bokhovchuk FM, Bate N, Kovalevskaya NV, Goult BT, Spronk C, Vuister GW. The Structural Basis of Calcium-Dependent Inactivation of the Transient Receptor Potential Vanilloid 5 Channel. Biochemistry. 2018;57(18):2623-35.

11. de Groot T, Kovalevskaya NV, Verkaart S, Schilderink N, Felici M, van der Hagen EA, et al. Molecular mechanisms of calmodulin action on TRPV5 and modulation by parathyroid hormone. Mol Cell Biol. 2011;31(14):2845-53.

12. Kovalevskaya NV, Bokhovchuk FM, Vuister GW. The TRPV5/6 calcium channels contain multiple calmodulin binding sites with differential binding properties. J Struct Funct Genomics. 2012;13(2):91-100.

13. Lambers TT, Weidema AF, Nilius B, Hoenderop JG, Bindels RJ. Regulation of the mouse epithelial $\mathrm{Ca} 2(+)$ channel TRPV6 by the $\mathrm{Ca}(2+)$-sensor calmodulin. J Biol Chem. 2004;279(28):28855-61. 
bioRxiv preprint doi: https://doi.org/10.1101/2021.02.16.431366; this version posted February 16, 2021. The copyright holder for this preprint (which was not certified by peer review) is the author/funder, who has granted bioRxiv a license to display the preprint in perpetuity. It is made available under aCC-BY 4.0 International license.

14. Nilius B, Weidema F, Prenen J, Hoenderop JG, Vennekens R, Hoefs S, et al. The carboxyl terminus of the epithelial $\mathrm{Ca}(2+)$ channel $\mathrm{ECaC} 1$ is involved in $\mathrm{Ca}(2+)$-dependent inactivation. Pflugers Arch. 2003;445(5):584-8.

15. Ben-Johny M, Yue DT. Calmodulin regulation (calmodulation) of voltage-gated calcium channels. J Gen Physiol. 2014;143(6):679-92.

16. Dang S, van Goor MK, Asarnow D, Wang Y, Julius D, Cheng Y, et al. Structural insight into TRPV5 channel function and modulation. Proc Natl Acad Sci U S A. 2019;116(18):886978.

17. Hughes TET, Pumroy RA, Yazici AT, Kasimova MA, Fluck EC, Huynh KW, et al. Structural insights on TRPV5 gating by endogenous modulators. Nat Commun. 2018;9(1):4198.

18. Singh AK, McGoldrick LL, Twomey EC, Sobolevsky Al. Mechanism of calmodulin inactivation of the calcium-selective TRP channel TRPV6. Sci Adv. 2018;4(8):eaau6088.

19. Holakovska B, Grycova L, Bily J, Teisinger J. Characterization of calmodulin binding domains in TRPV2 and TRPV5 C-tails. Amino Acids. 2011;40(2):741-8.

20. Lai M, Brun D, Edelstein SJ, Le Novere N. Modulation of calmodulin lobes by different targets: an allosteric model with hemiconcerted conformational transitions. PLoS Comput Biol. 2015;11(1):e1004063.

21. Gonzalez-Munoz E, Lopez-Iglesias C, Calvo M, Palacin M, Zorzano A, Camps M. Caveolin1 loss of function accelerates glucose transporter 4 and insulin receptor degradation in 3T3-L1 adipocytes. Endocrinology. 2009;150(8):3493-502.

22. Perez-Verdaguer M, Capera J, Ortego-Dominguez M, Bielanska J, Comes N, Montoro RJ, et al. Caveolar targeting links Kv1.3 with the insulin-dependent adipocyte physiology. Cell Mol Life Sci. 2018;75(21):4059-75.

23. Fruen BR, Black DJ, Bloomquist RA, Bardy JM, Johnson JD, Louis CF, et al. Regulation of the RYR1 and RYR2 Ca2+ release channel isoforms by Ca2+-insensitive mutants of calmodulin. Biochemistry. 2003;42(9):2740-7.

24. Ulbrich $\mathrm{MH}$, Isacoff EY. Subunit counting in membrane-bound proteins. Nat Methods. 2007;4(4):319-21.

25. McGuire $H$, Aurousseau MR, Bowie D, Blunck R. Automating single subunit counting of membrane proteins in mammalian cells. J Biol Chem. 2012;287(43):35912-21.

26. Saimi Y, Kung C. Calmodulin as an ion channel subunit. Annu Rev Physiol. 2002;64:289311. 
27. Hoenderop JG, van der Kemp AW, Hartog A, van Os $\mathrm{CH}$, Willems $\mathrm{PH}$, Bindels RJ. The epithelial calcium channel, ECaC, is activated by hyperpolarization and regulated by cytosolic calcium. Biochem Biophys Res Commun. 1999;261(2):488-92.

28. Chemin J, Taiakina V, Monteil A, Piazza M, Guan W, Stephens RF, et al. Calmodulin regulates Cav3 T-type channels at their gating brake. J Biol Chem. 2017;292(49):2001031.

29. Erickson MG, Alseikhan BA, Peterson BZ, Yue DT. Preassociation of calmodulin with voltage-gated $\mathrm{Ca}(2+)$ channels revealed by FRET in single living cells. Neuron. 2001;31(6):973-85.

30. Tien J, Peters CJ, Wong XM, Cheng $\mathrm{T}$, Jan YN, Jan LY, et al. A comprehensive search for calcium binding sites critical for TMEM16A calcium-activated chloride channel activity. Elife. 2014;3.

31. Zurborg S, Yurgionas B, Jira JA, Caspani O, Heppenstall PA. Direct activation of the ion channel TRPA1 by Ca2+. Nat Neurosci. 2007;10(3):277-9.

32. Derler I, Hofbauer M, Kahr H, Fritsch R, Muik M, Kepplinger K, et al. Dynamic but not constitutive association of calmodulin with rat TRPV6 channels enables fine tuning of Ca2+-dependent inactivation. J Physiol. 2006;577(Pt 1):31-44.

33. Adams PJ, Ben-Johny M, Dick IE, Inoue T, Yue DT. Apocalmodulin itself promotes ion channel opening and $\mathrm{Ca}(2+)$ regulation. Cell. 2014;159(3):608-22.

34. Wen $\mathrm{H}$, Levitan IB. Calmodulin is an auxiliary subunit of KCNQ2/3 potassium channels. J Neurosci. 2002;22(18):7991-8001.

35. Bernardo-Seisdedos G, Nunez E, Gomis-Perez C, Malo C, Villarroel A, Millet O. Structural basis and energy landscape for the $\mathrm{Ca}(2+)$ gating and calmodulation of the $\mathrm{Kv7.2} \mathrm{K}(+)$ channel. Proc Natl Acad Sci U S A. 2018;115(10):2395-400.

36. Chang A, Abderemane-Ali F, Hura GL, Rossen ND, Gate RE, Minor DL, Jr. A Calmodulin CLobe Ca(2+)-Dependent Switch Governs Kv7 Channel Function. Neuron. 2018;97(4):83652 e6.

37. Chin D, Means AR. Calmodulin: a prototypical calcium sensor. Trends Cell Biol. 2000;10(8):322-8.

38. Bagur R, Hajnoczky G. Intracellular $\mathrm{Ca}(2+)$ Sensing: Its Role in Calcium Homeostasis and Signaling. Mol Cell. 2017;66(6):780-8.

39. Hasan R, Zhang X. Ca(2+) Regulation of TRP Ion Channels. Int J Mol Sci. 2018;19(4). 
40. Banerjee R, Yoder JB, Yue DT, Amzel LM, Tomaselli GF, Gabelli SB, et al. Bilobal architecture is a requirement for calmodulin signaling to CaV1.3 channels. Proc Natl Acad Sci U S A. 2018;115(13):E3026-E35.

41. Nakajo K, Ulbrich MH, Kubo Y, Isacoff EY. Stoichiometry of the KCNQ1 - KCNE1 ion channel complex. Proc Natl Acad Sci U S A. 2010;107(44):18862-7.

42. Halling DB, Kenrick SA, Riggs AF, Aldrich RW. Calcium-dependent stoichiometries of the KCa2.2 (SK) intracellular domain/calmodulin complex in solution. J Gen Physiol. 2014;143(2):231-52.

43. Ben-Johny M, Yue DN, Yue DT. Detecting stoichiometry of macromolecular complexes in live cells using FRET. Nat Commun. 2016;7:13709.

44. Nunez E, Muguruza-Montero A, Villarroel A. Atomistic Insights of Calmodulin Gating of Complete Ion Channels. Int J Mol Sci. 2020;21(4).

45. Geiser JR, van Tuinen D, Brockerhoff SE, Neff MM, Davis TN. Can calmodulin function without binding calcium? Cell. 1991;65(6):949-59.

46. Xia XM, Fakler B, Rivard A, Wayman G, Johnson-Pais T, Keen JE, et al. Mechanism of calcium gating in small-conductance calcium-activated potassium channels. Nature. 1998;395(6701):503-7.

47. Perez-Verdaguer M, Capera J, Martinez-Marmol R, Camps M, Comes N, Tamkun MM, et al. Caveolin interaction governs Kv1.3 lipid raft targeting. Sci Rep. 2016;6:22453.

48. Moreno C, Oliveras A, de la Cruz A, Bartolucci C, Munoz C, Salar E, et al. A new KCNQ1 mutation at the S5 segment that impairs its association with KCNE1 is responsible for short QT syndrome. Cardiovasc Res. 2015;107(4):613-23.

49. Schindelin J, Arganda-Carreras I, Frise E, Kaynig V, Longair M, Pietzsch T, et al. Fiji: an open-source platform for biological-image analysis. Nat Methods. 2012;9(7):676-82.

50. Reuel NF, Bojo P, Zhang J, Boghossian AA, Ahn JH, Kim JH, et al. NoRSE: noise reduction and state evaluator for high-frequency single event traces. Bioinformatics. 2012;28(2):296-7.

51. Chung SH, Kennedy RA. Forward-backward non-linear filtering technique for extracting small biological signals from noise. J Neurosci Methods. 1991;40(1):71-86.

52. Coffman VC, Wu P, Parthun MR, Wu JQ. CENP-A exceeds microtubule attachment sites in centromere clusters of both budding and fission yeast. J Cell Biol. 2011;195(4):56372. 
bioRxiv preprint doi: https://doi.org/10.1101/2021.02.16.431366; this version posted February 16, 2021. The copyright holder for this preprint (which was not certified by peer review) is the author/funder, who has granted bioRxiv a license to display the preprint in perpetuity. It is made available under aCC-BY 4.0 International license.

53. Leake MC, Chandler JH, Wadhams GH, Bai F, Berry RM, Armitage JP. Stoichiometry and

704 turnover in single,

functioning

membrane

protein

complexes.

Nature. 2006;443(7109):355-8.

706 
Figure legends

708

709 Figure 1. Constitutive and $\mathrm{Ca}^{2+}$-dependent interaction of TRPV5 and CaM. A. Interaction of

710 mCherry-TRPV5 with CaM-eGFP and the $\mathrm{Ca}^{2+}$-insensitive mutants CaM12-eGFP, CaM34-

711 eGFP and CaM1234-eGFP in HEK293 cells was addressed by FLIM-FRET. Representative

712 images are shown for the donors (CaM-eGFP and indicated mutants) and acceptor

713 (mCherry-TRPV5) expression, merged channels (donors: green, acceptor: magenta, co-

714 localization: light pink or white) and FLIM-FRET. Example of measured ROIs represented as

715 red boxes on the FLIM-FRET image. Bars represent $10 \mu \mathrm{m}$. B. Life time decay of CaM

wildtype and mutants in the presence of mock or TRPV5, depicted as single measurements

717 of ROls at cytoplasmic colocalization ( $n=30-38$ cells). * indicates $p<0.05$ compared to mock

within each condition (ANOVA). C. Immunoprecipitations of HEK293 cells expressing either

mock eGFP (pcDNA), mock GST (pEBG), or GST-tagged CaM wildtype and indicated mutants

with eGFP-TRPV5. Representative immunoblots are shown for total lysate (bottom two

pulldown of HEK293 cells expressing either mock eGFP or eGFP-TRPV5, in the presence of increasing $\mathrm{Ca}^{2+}$ concentrations in the lysis buffer. Representative immunoblots are shown

for the pulldown (top lane) of eGFP-TRPV5 and total lysate (bottom two lanes) of TRPV5 and

ß-actin, as loading control. E. Semi-quantification of CaM pulldown experiments expressed as mean \pm SEM ( $n=2-4)$. Intensity of TRPV5 pulldown lanes were normalized to TRPV5 total lysate. Dotted line indicates value at $0 \mu \mathrm{M} \mathrm{Ca}{ }^{2+}$. F. FLIM-FRET analysis of mCherry-TRPV5 with CaM-eGFP in PMLs of HEK293 cells washed with either $\mathrm{Ca}^{2+}$-containing $(2 \mathrm{mM})$ or $\mathrm{Ca}^{2+}$ free (2 mM EGTA, 2 mM EDTA) buffer. Representative images are shown for the donor 
$\mu \mathrm{m}$. G. Life time decay of CaM in the presence of mock or TRPV5, depicted as single measurements of ROls, for either $\mathrm{Ca}^{2+}$-containing or $\mathrm{Ca}^{2+}$-free condition ( $\mathrm{n}=14-15$ cells). ROIs for analysis were drawn throughout the PML. * indicates $\mathrm{p}<0.05$ compared to mock within each condition (ANOVA).

Figure 1 - figure supplement 1. Preparation of plasma membrane lawns (PMLs). A. that lead unroofing the cells leaving the membranes attached to the glass coverslip. B. 680 membrane marker as well as of transmitted light in the whole cells and unroofed cells.

Bars represent $20 \mu \mathrm{m}$. C. Representative images of eGFP-CaM, mCherry-TRPV5 and the point to whole cells, green arrows to PMLs.

Figure 2. CaM C-lobe as major determinant for binding TRPV5. A. Structural overview of

750 the interaction interface of $\mathrm{Ca}^{2+}$-bound CaM (pink) with the TRPV5 C-terminal helices (blue).

$751 \mathrm{Ca}^{2+}$ ions are depicted as cyan. B. Peptide pulldown of mock- or GST-CaM expressing HEK293

752 cells. Representative immunoblots are shown for total lysate and streptavidin pulldown with either the biotin-linked distal or proximal TRPV5 peptides. C. CaM agarose pulldown of 
$(0-100 \mu \mathrm{M})$ of either the proximal or distal TRPV5 peptides. Representative immunoblots are shown for eGFP-TRPV5 pulldown and total lysate. D-E. Semi-quantification of CaM pulldown experiments expressed as mean \pm SEM $(n=3)$. Intensity of TRPV5 pulldown lanes were expressed against the proximal (D) or distal (E) peptide concentration and the graphs were fitted using a non-linear sigmoidal correlation. $\mathrm{R}^{2}$ is indicated in the graph.

Figure 2 - figure supplement 1. Interaction interface of TRPV5-CaM. Interaction of mCherry-TRPV5 wildtype and indicated mutants with CaM-eGFP in HEK293 cells was addressed by FLIM-FRET. A. Representative images are shown for the donor (CaM-eGFP) and acceptors (mCherry-TRPV5 WT and mutants) expression, merged channels (donors: green, acceptor: magenta, co-localization: light pink or white) and FLIM-FRET image. Scale bars represent $10 \mu \mathrm{m}$. B. Life time decay of CaM in the presence of mock, TRPV5 wildtype or indicated mutants, depicted as single measurements of ROls at cytoplasmic colocalization ( $n=25-30$ cells). C. Life time decay of CaM1234 in the presence of mock, TRPV5 wildtype or indicated mutants, depicted as single measurements of ROls at cytoplasmic colocalization ( $n=15-20$ cells). ${ }^{*}$ indicates $p<0.05$ compared to mock (ANOVA), and $\#$ indicates $p<0.05$ compared to the TRPV5 wildtype condition (ANOVA).

Figure 2 - Source data 1 . Original immunoblot density calculations for figure 2D.

Figure 2 - Source data 2. Original immunoblot density calculations for figure $2 \mathrm{E}$. 
bioRxiv preprint doi: https://doi.org/10.1101/2021.02.16.431366; this version posted February 16, 2021. The copyright holder for this preprint (which was not certified by peer review) is the author/funder, who has granted bioRxiv a license to display the preprint in perpetuity. It is made available under aCC-BY 4.0 International license.

mock or CaM-eGFP wildtype or $\mathrm{Ca}^{2+}$-insensitive mutants (CaM12, CaM34, CaM1234). The $340 / 380 \mathrm{~nm}$ ratiometric changes are shown as averaged data points \pm SEM over time $(n=80-$ 160 cells), with addition of $\mathrm{Ca}^{2+}$-containing buffer $\left(2 \mathrm{mM} \mathrm{Ca}^{2+}\right)$ indicated by the arrow. TRPV5 and mock (open squares), TRPV5 and CaM (light grey circles), TRPV5 and CaM12 (grey upfacing triangles), TRPV5 and CaM34 (dark grey downfacing triangles), TRPV5 and CaM1234 (black diamonds). B. Bar graph of the Fura-2 peak response, measured as the ratio of response (mean of four values after $\mathrm{Ca}^{2+}$ addition) and baseline (average of five reference values), for the indicated conditions. ${ }^{*}$ indicates $p<0.05$ compared to TRPV5/mock within each condition (ANOVA). C. FLIM-FRET analysis to address the interaction of mCherry-TRPV5 with CaM-eGFP or the separate lobes, CaM N-lobe-eGFP and CaM C-lobe-eGFP, in HEK293 cells. Life time decay of CaM wildtype or N-/C-lobes in the presence of mock or TRPV5, depicted as single measurements of ROls at cytoplasmic colocalization ( $n=24-30$ cells). * indicates $p<0.05$ compared to mock within each condition (ANOVA). D. Peptide pulldown of HEK293 cells expressing mock, GST-CaM, GST-N-lobe, or GST-C-lobe. Representative immunoblots are shown for total lysate and streptavidin pulldown with either the biotinlinked distal or proximal TRPV5 peptides. E. Intracellular $\mathrm{Ca}^{2+}$ measurements with Fura2-AM of HEK293 cells expressing mCherry-TRPV5 with either mock, CaM-eGFP wildtype or the separate lobes (CaM N-lobe-eGFP and CaM C-lobe-eGFP). The 340/380nm ratiometric changes are shown as averaged data points \pm SEM over time ( $n=130-200$ cells), with addition of $\mathrm{Ca}^{2+}$-containing buffer $\left(2 \mathrm{mM} \mathrm{Ca}^{2+}\right)$ indicated by the arrow. TRPV5 and mock (open squares), TRPV5 and CaM (light grey circles), TRPV5 and CaM N-lobe (grey diamond), TRPV5 and CaM C-lobe (dark grey upfacing triangles). F. Bar graph of the Fura-2 peak response, measured as the ratio of response (mean of four values after $\mathrm{Ca}^{2+}$ addition) and baseline (average of five reference values), for the indicated conditions. * indicates $p<0.05$ 
compared to TRPV5/mock within each condition (ANOVA). G-H. FLIM-FRET analysis of mCherry-TRPV5 with either CaM-eGFP, CaM N-lobe-eGFP or CaM C-lobe-eGFP in PMLs of HEK293 cells washed with $\mathrm{Ca}^{2+}$-containing $(2 \mathrm{mM})(\mathbf{G})$ or $\mathrm{Ca}^{2+}$-free $(2 \mathrm{mM}$ EGTA, 2 mM EDTA) buffer $(\mathbf{H})$. Representative images are shown for the donors (CaM-eGFP and indicated lobes) and acceptor (mCherry-TRPV5) expression, merged channels (donors: green, acceptor: magenta, co-localization: light pink or white) and FLIM-FRET. Bars represent $10 \mu \mathrm{m}$. I-J. Life

809 time decay of CaM or N-/C-lobes in the presence of mock or TRPV5, depicted as single measurements of PMLs, for either $\mathrm{Ca}^{2+}$-containing ( $\mathrm{n}=25-40$ cells) (I) or $\mathrm{Ca}^{2+}$-free condition

811 (J) ( $n=10-25$ cells). ROIs for analysis were drawn throughout the PML and where both proteins colocalized. * indicates $p<0.05$ compared to mock within each condition (ANOVA).

Figure 3 - figure supplement $1 . \mathbf{N}$ - and C-Lobe interaction with TRPV5. Interaction of CaM WT, N-Lobe and C-Lobe with mCherry-TRPV5 in HEK293 cells was addressed by FLIM-FRET. acceptors (mock or mCherry-TRPV5) expression, merged channels (donors: green, acceptor: magenta, co-localization: light pink or white) and FLIM-FRET image. Scale bars represent 10 $\mu \mathrm{m}$.

Figure 3 - Source data 1. Original peak response values for figure 3B.

Figure 3 - Source data 2. Original peak response values for figure 3F.

Figure 4 Stoichiometry of CaM binding to TRPV5. A. A single frame from a TIRF movie of a 
lines indicate the fluorescence intensity of single eGFP fluorophores. Green arrows point the

Figure 4-source data 1. Original values on observed and calculated number of spots for

figure 4C.

Figure 4-source data 2. Original values on observed and calculated number of spots for

figure 4G.

Figure 4-source data 3. Original values on probabilities for figure $4 \mathrm{H}$. 
851 ApoCaM pre-associates with TRPV5, but it is not blocking ion conduction of the channel (left

852 panel). At low basal $\mathrm{Ca}^{2+}$ concentrations, the C-lobe can get calcified and obstruct the

853 bottom pore of TRPV5 (central panel). Upon increased $\mathrm{Ca}^{2+}$ concentrations, the N-lobe will

854 interact with $\mathrm{Ca}^{2+}$ and further enhance the inactivated complex (right panel). There are 2

855 CaM molecules that can interact with a TRPV5 channel at any given time, while there is only

8561 CaM C-lobe effectively blocking the channel pore.

857

858 


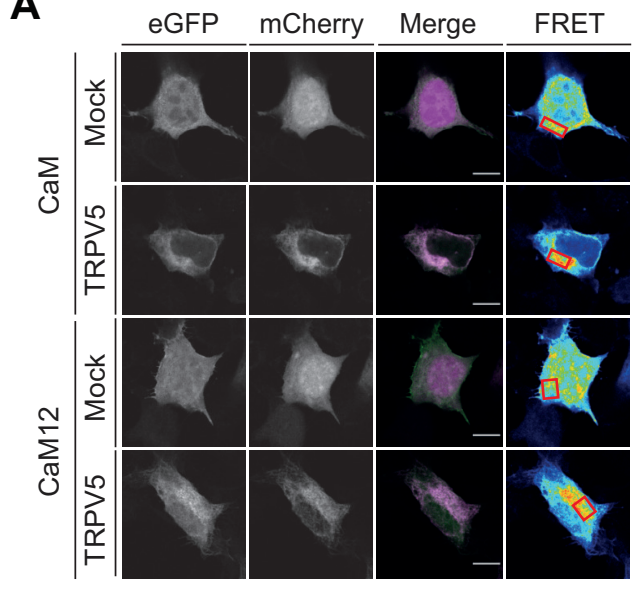

C

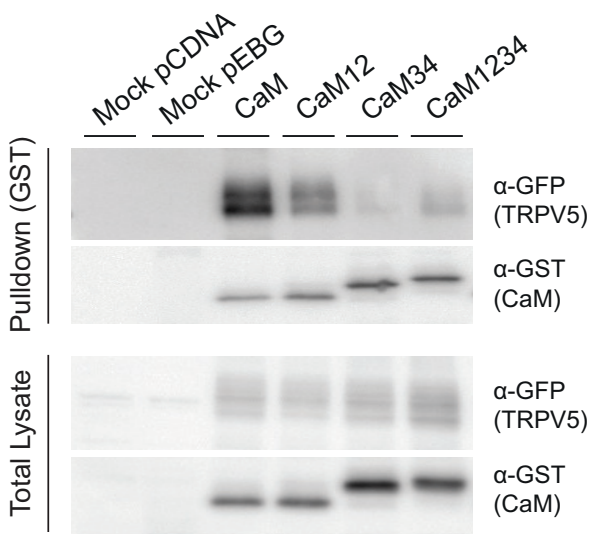

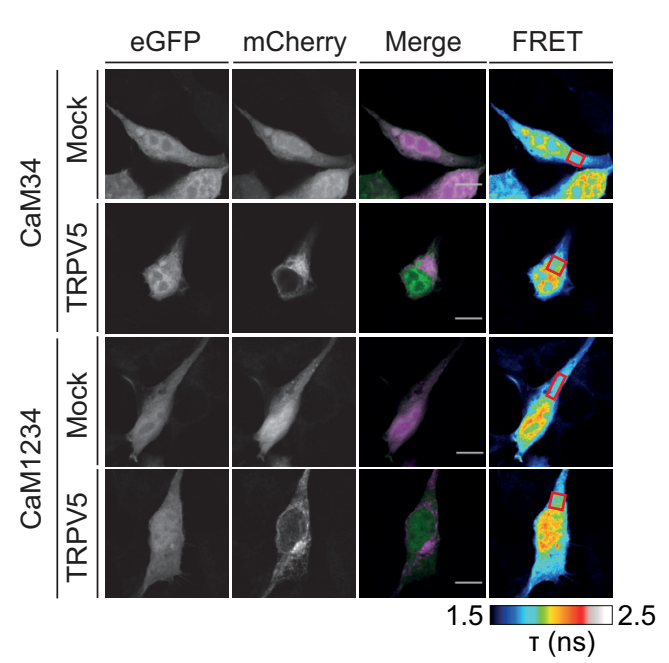

D

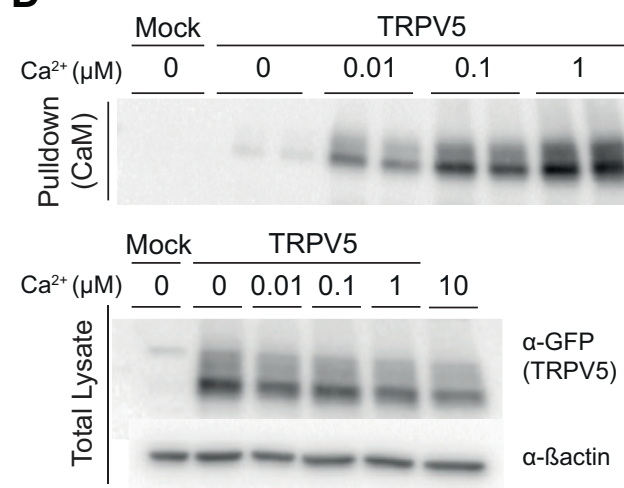

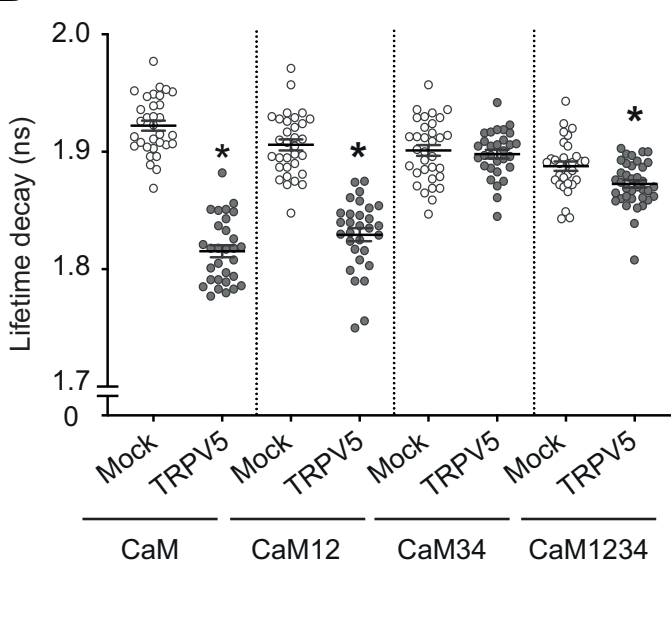

E

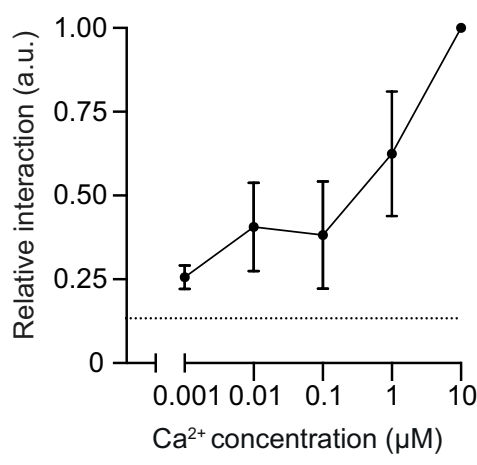

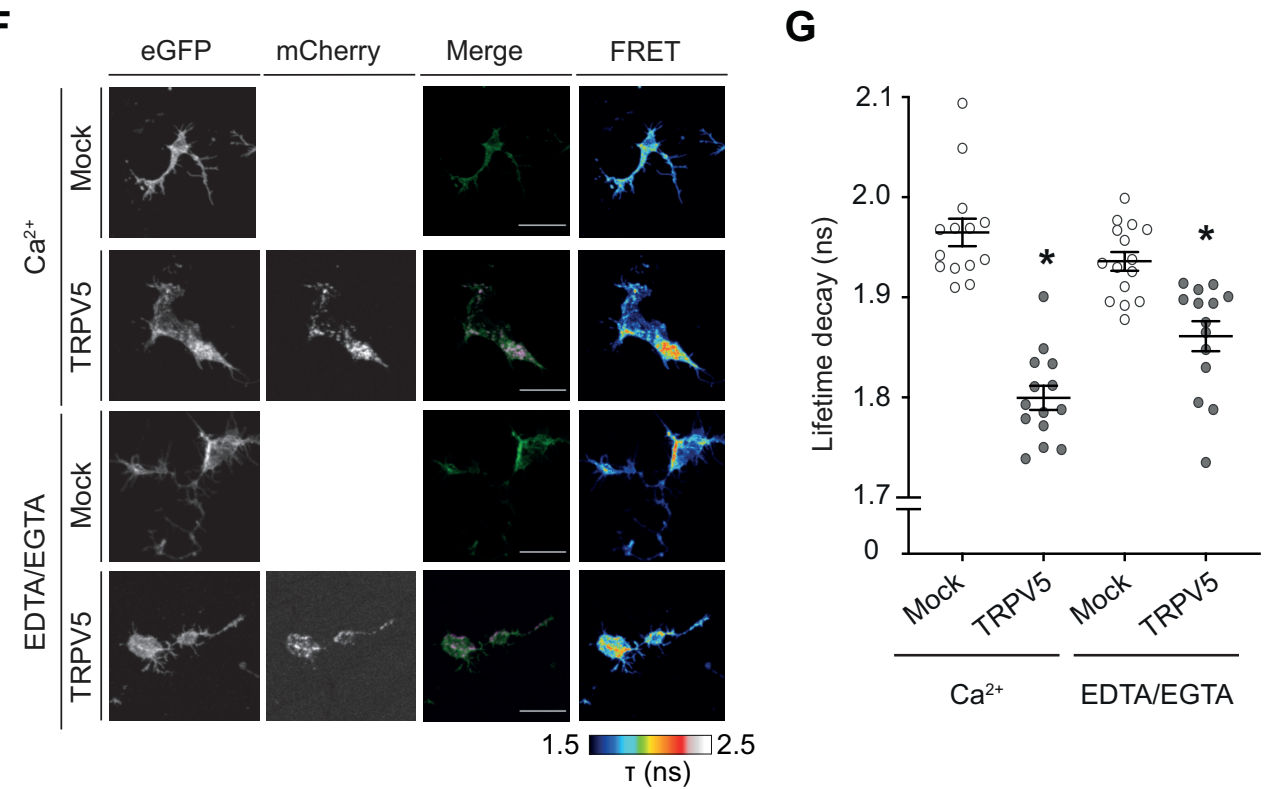




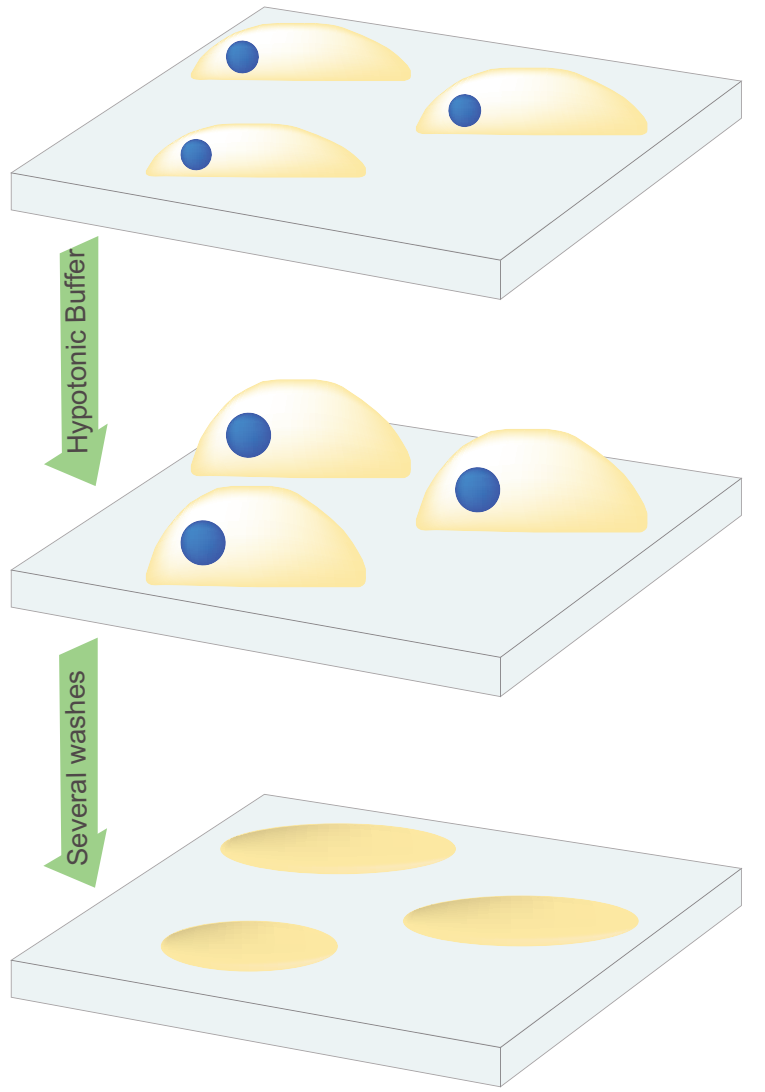

B

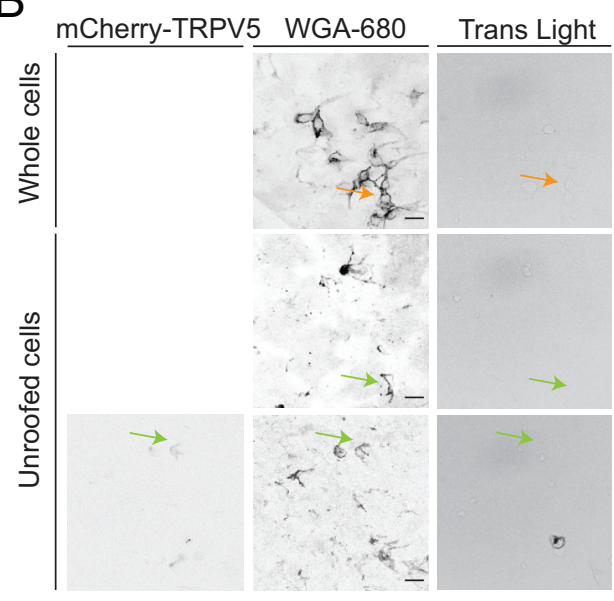

C

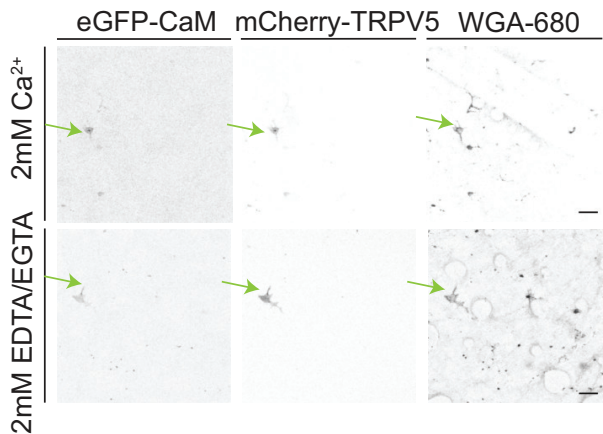


A

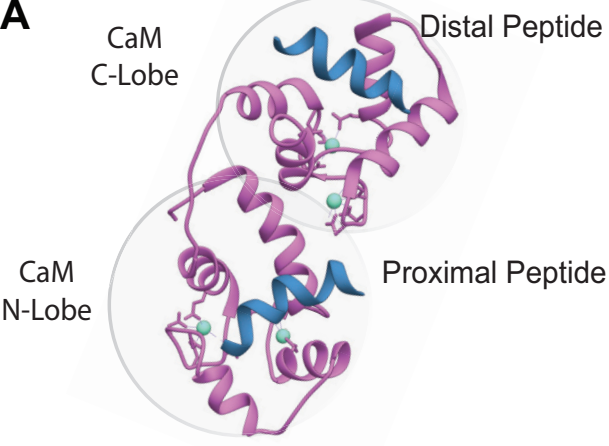

B

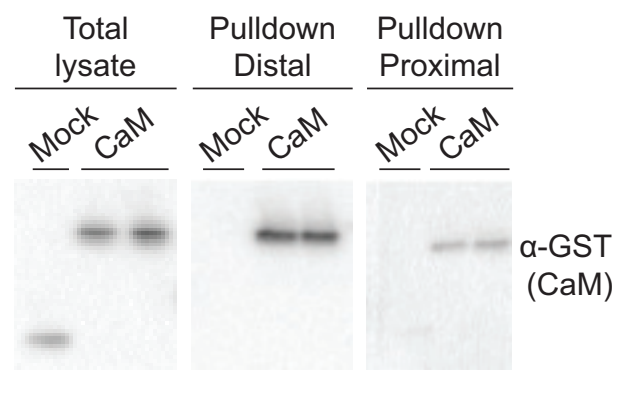

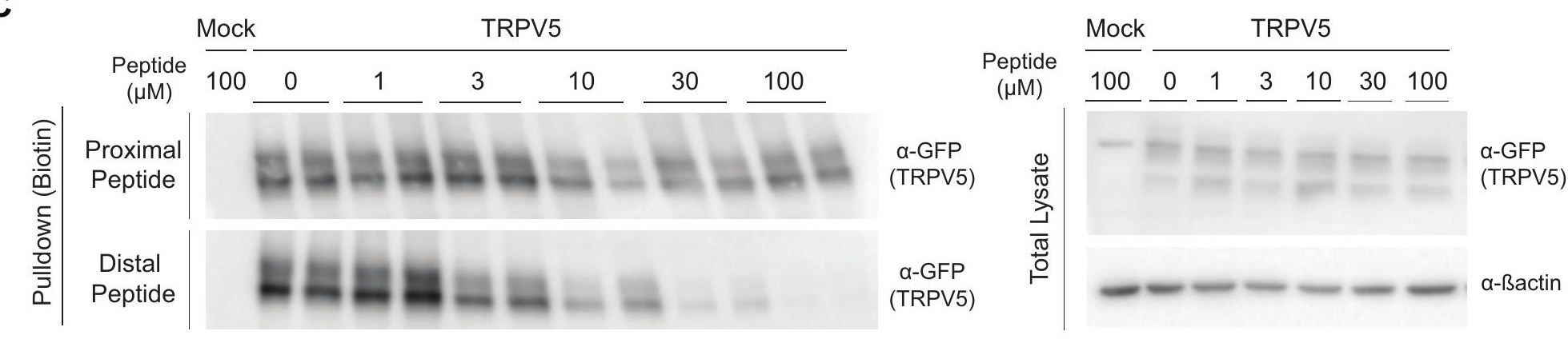

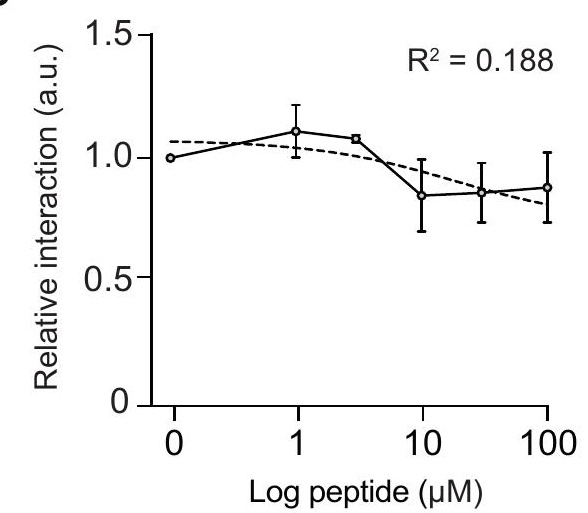

E

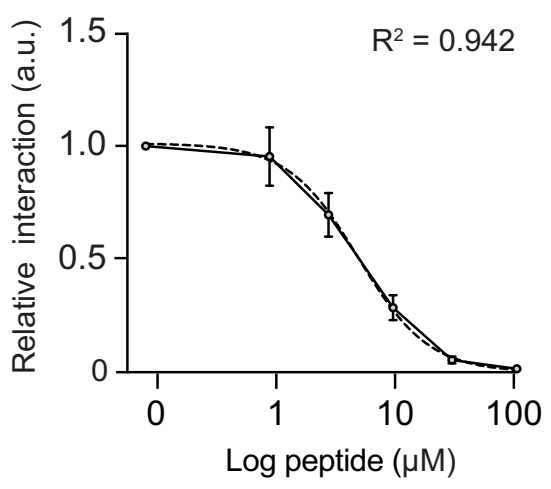




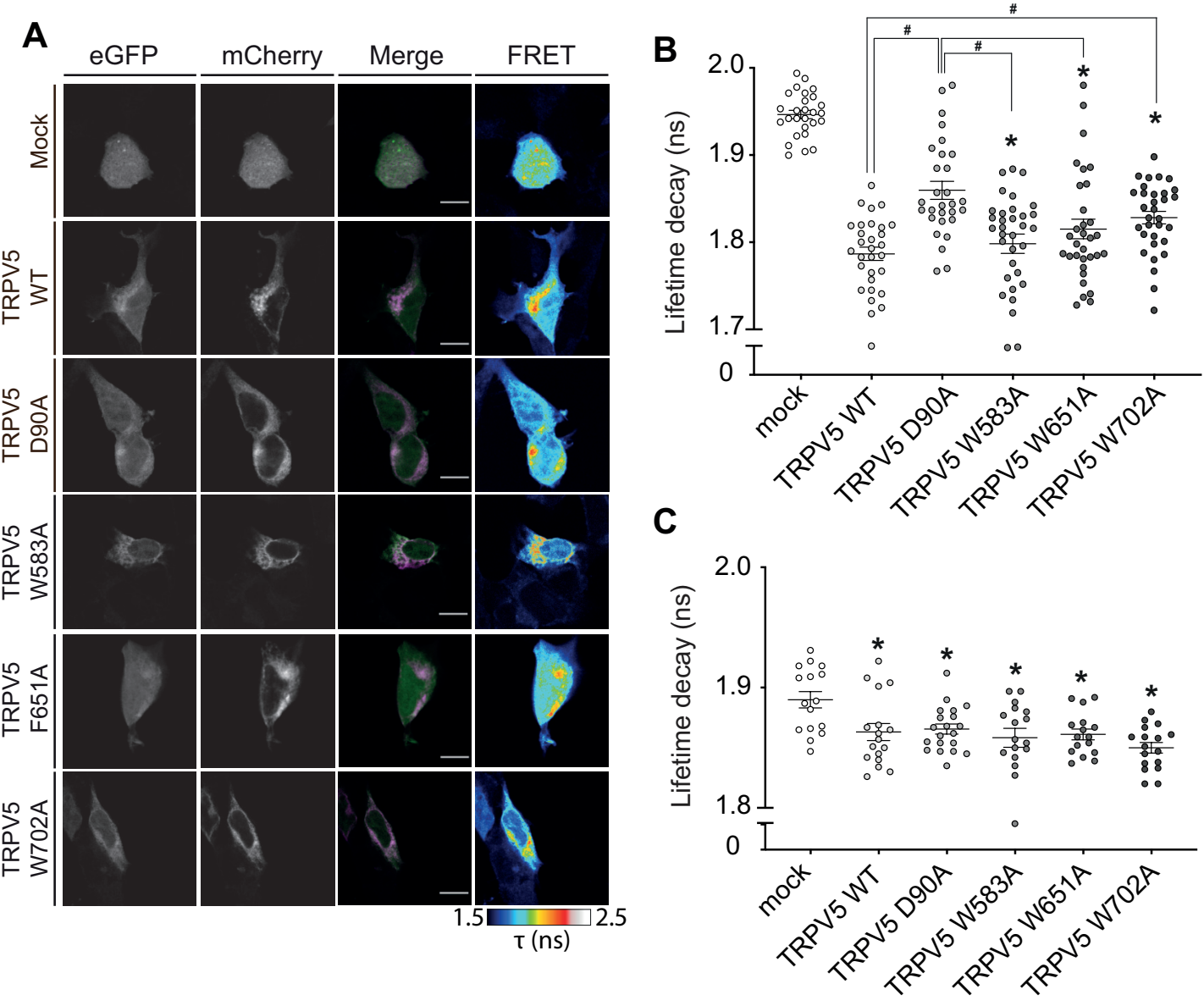


A

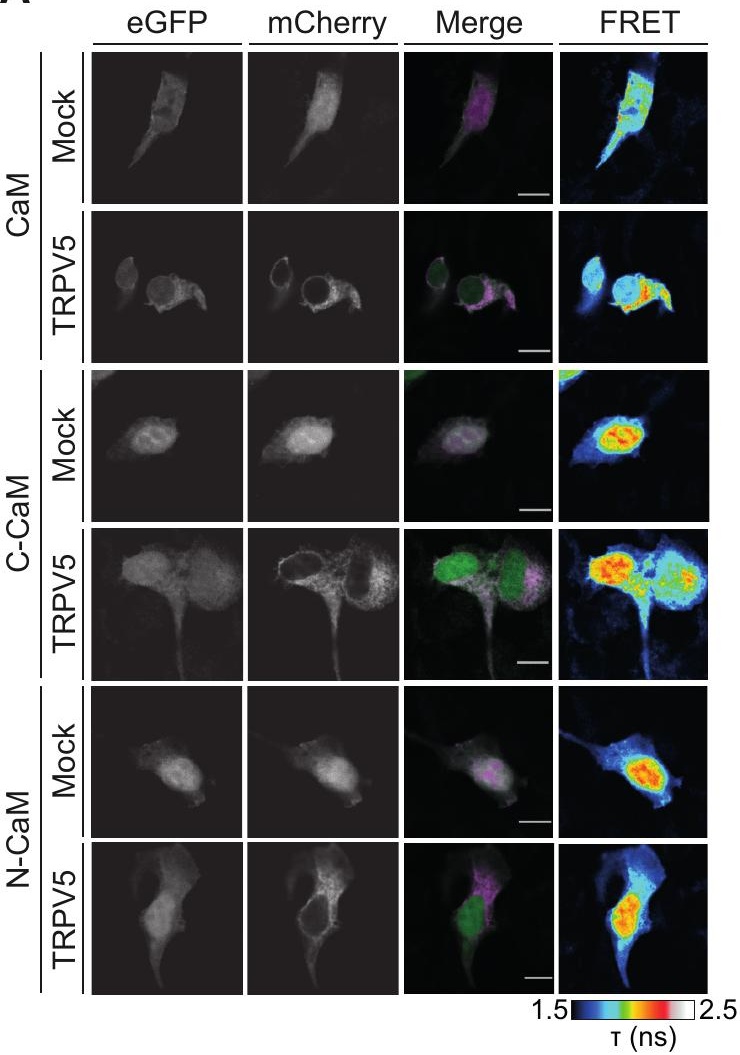


eGFP-TRPV5 $\quad \mathbf{B}_{\frown}$
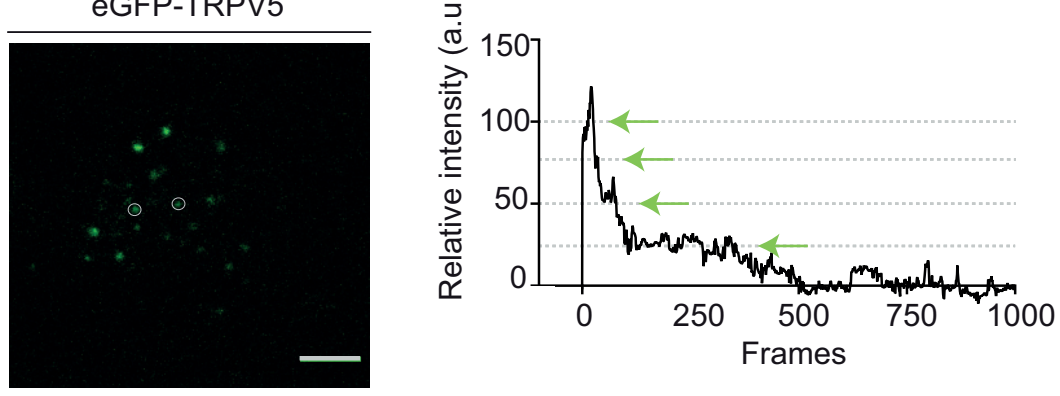

C

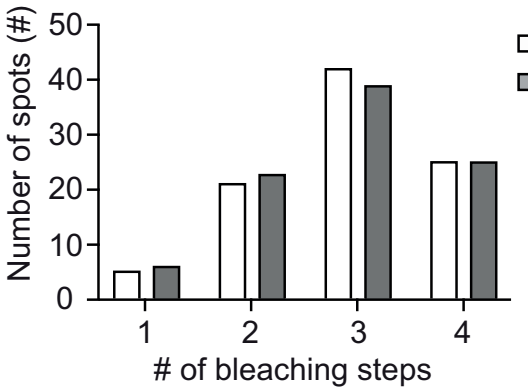

$\square$ Observed

$\square$ Calculated $(p=72 \%)$
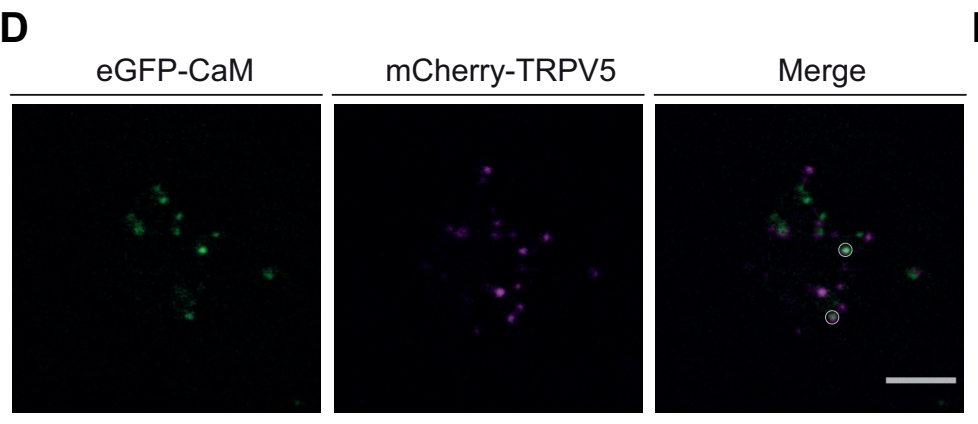

E
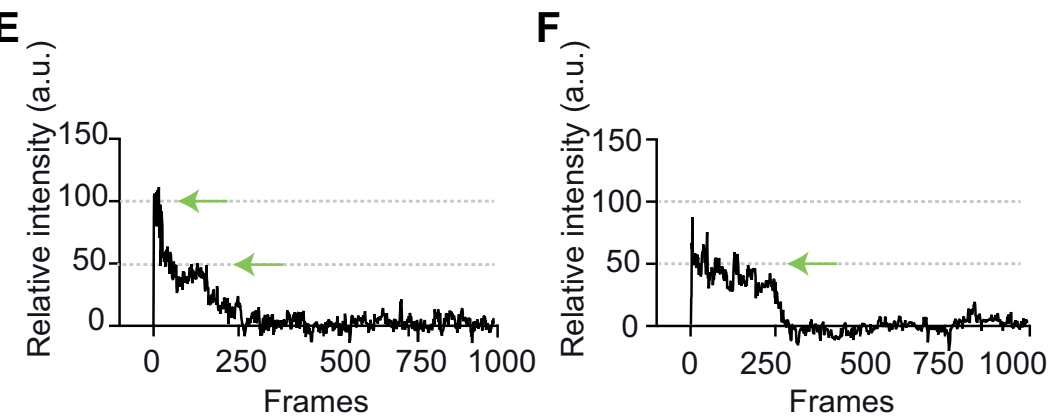

G

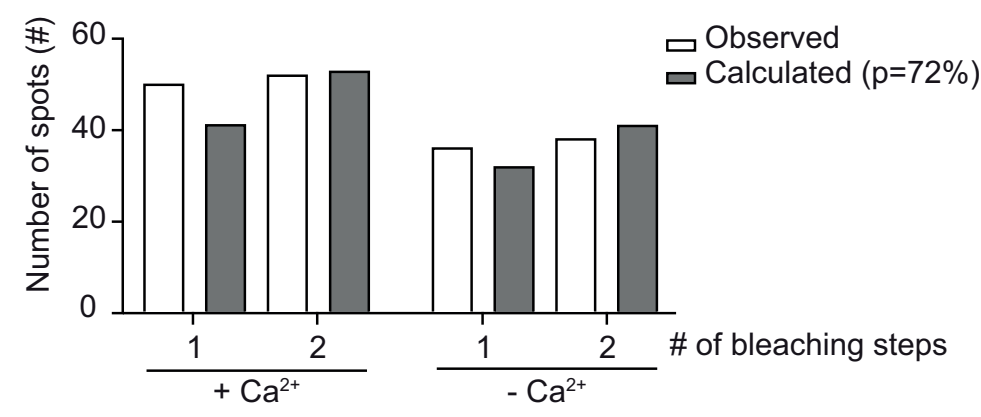

H

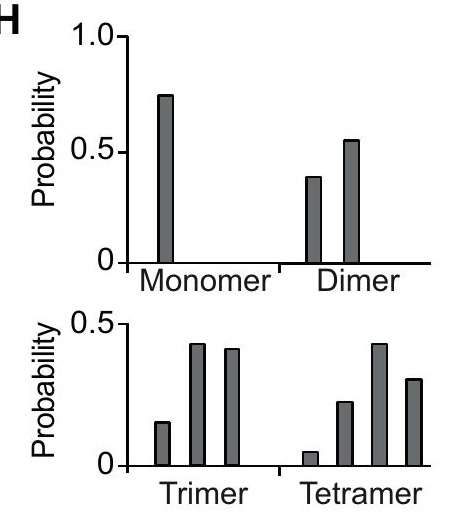




\section{intracellular $\mathrm{Ca}^{2+}$}

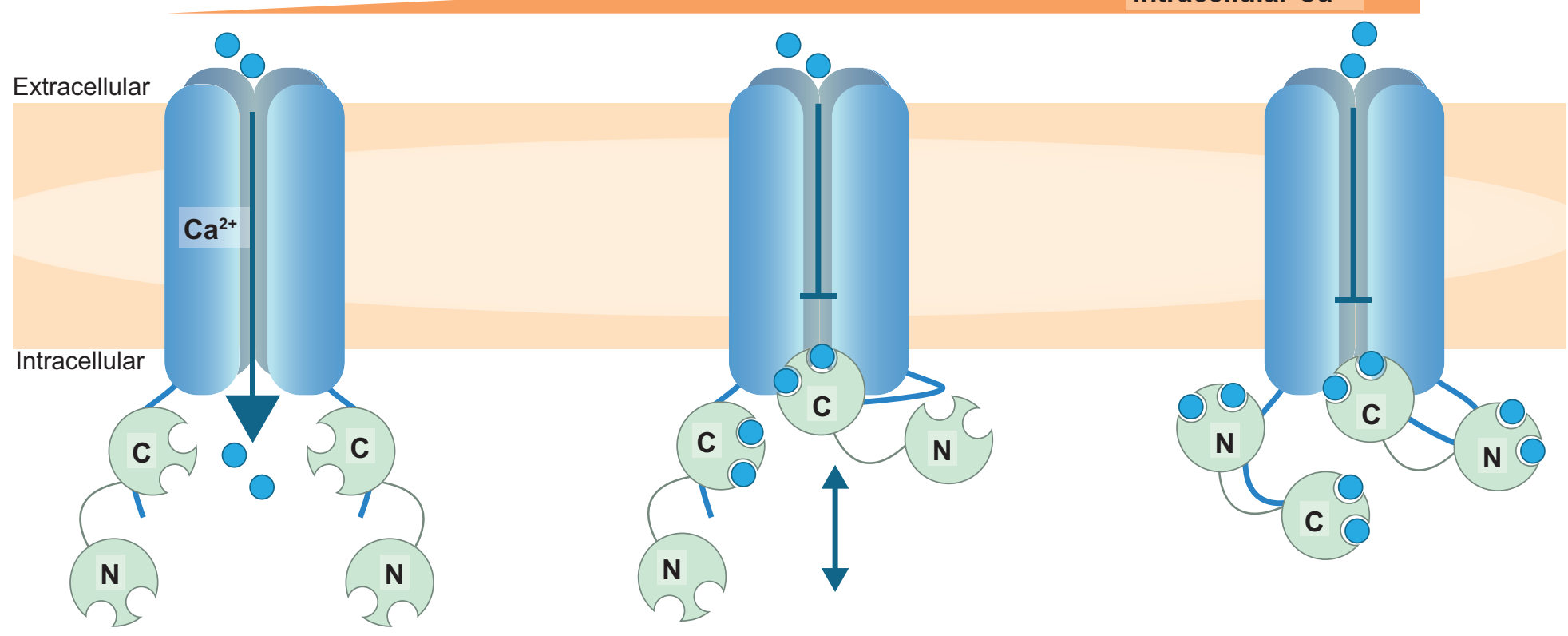

